\title{
Submersed Littoral Vegetation Distribution: Field Quantification and Experimental Analysis of Sediment Types from Onondaga Lake, New York
}

\author{
by John D. Madsen, R. Michael Smart \\ Environmental Laboratory
}

Lawrence W. Eichler, Charles W. Boylen

Rensselaer Polytechnic Institute

James W. Sutherland, Jay A. Bloomfield

New York State Department of Environmental Conservation 


\section{Submersed Littoral Vegetation Distribution: Field Quantification and Experimental Analysis of Sediment Types from Onondaga Lake, New York}

by John D. Madsen, R. Michael Smart

Environmental Laboratory

U.S. Army Corps of Engineers

Waterways Experiment Station

3909 Halls Ferry Road

Vicksburg, MS 39180-6199

Lawrence W. Eichler, Charles W. Boylen

Rensselaer Polytechnic Institute

Troy, NY 12180-3590

James W. Sutherland, Jay A. Bloomfield

New York State Department of Environmental Conservation

Albany, NY 12233-3502

Final report

Approved for public release; distribution is unlimited 


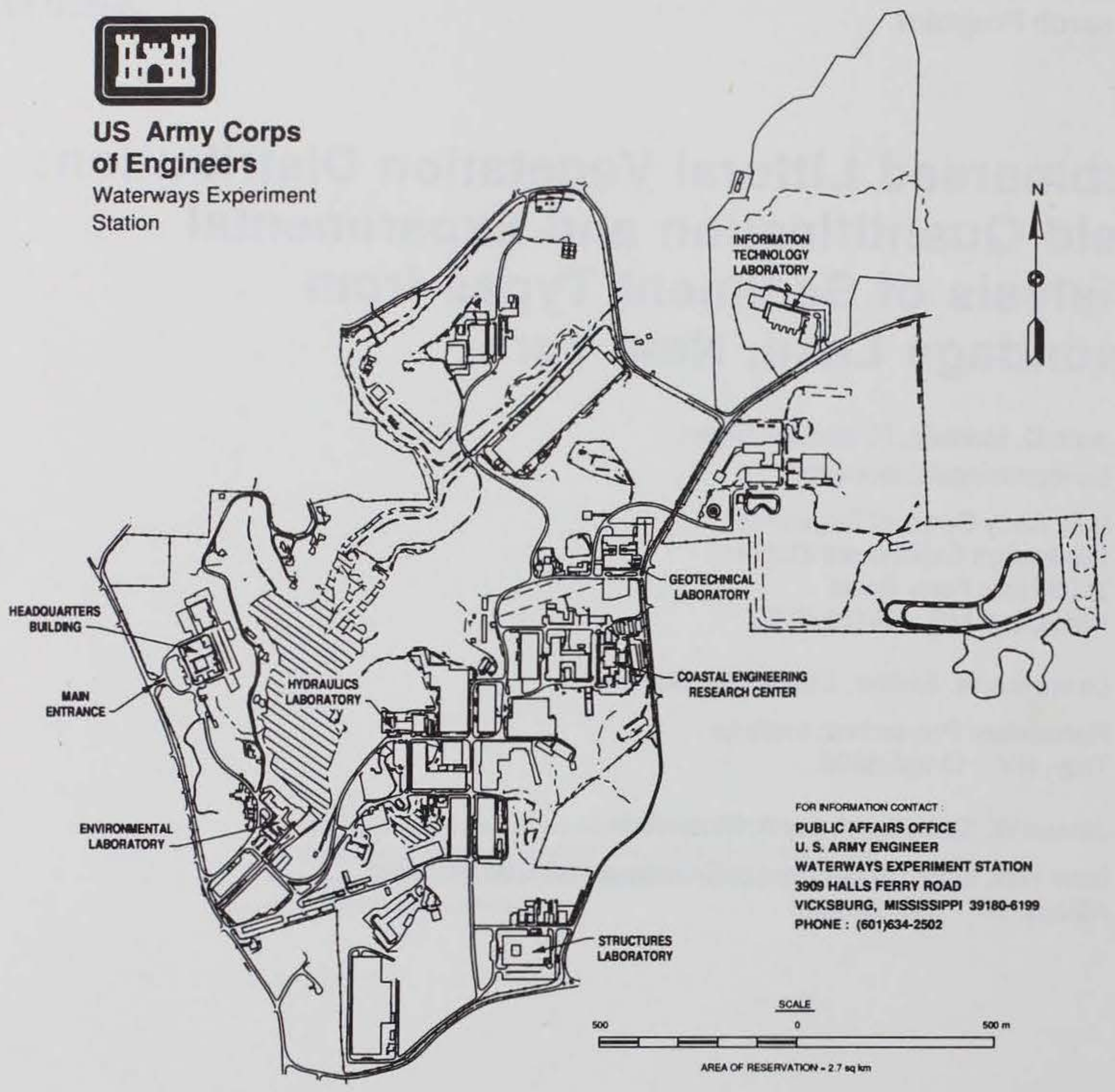

\section{Waterways Experiment Station Cataloging-in-Publication Data}

Submersed littoral vegetation distribution : field quantification and experimental analysis of sediment types from Onondaga Lake, New York / by John D. Madsen ... [et al.] ; prepared for U.S. Army Corps of Engineers.

60 p. : ill. ; $28 \mathrm{~cm}$. - (Technical report ; A-93-14)

Includes bibliographical references.

1. Lake renewal - New York (State) - Lake Onondaga. 2. Lake sediments - New York (State) - Lake Onondaga. 3. Aquatic plants New York (State) - Lake Onondaga - Growth. 4. Lake Onondaga (N.Y.) I. Madsen, John Douglas. II. United States. Army. Corps of Engineers. III. U.S. Army Engineer Waterways Experiment Station. IV. Aquatic Plant Control Research Program (U.S. Army Engineer Waterways Experiment Station) V. Series: Technical report (U.S. Army Engineer Waterways Experiment Station) ; A-93-14. 


\section{Contents}

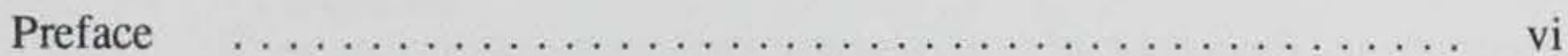

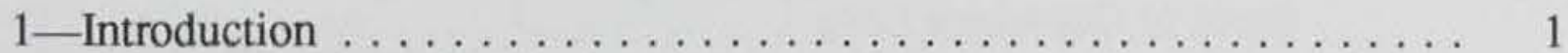

The Problem . . . . . . . . . . . . . . . . . . . . 1

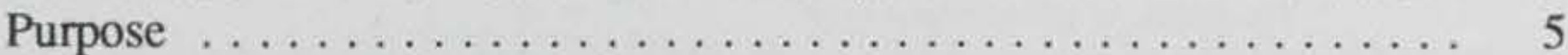

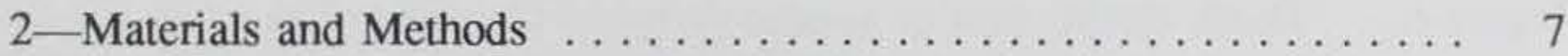

Field Studies . . . . . . . . . . . . . . . . . . 7

Greenhouse Studies . . . . . . . . . . . . . . . . . . . . . 9

General experimental setup $\ldots \ldots \ldots \ldots \ldots \ldots \ldots \ldots \ldots \ldots \ldots$

Laboratory analytical methods . . . . . . . . . . . . . 9

Sediment bioassay--survey . . . . . . . . . . . . . . . 10

Sediment bioassay--sediment types $\ldots \ldots \ldots \ldots \ldots \ldots \ldots \ldots \ldots 11$

Sediment/species bioassays . . . . . . . . . . . . . . 11

Seed bank studies . . . . . . . . . . . . . . . . . . 12

3-Results and Discussion ..................... 13

Field Studies . . . . . . . . . . . . . . . . . . . . . 13

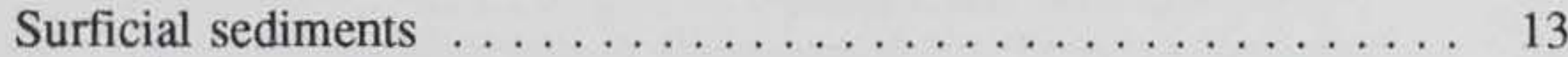

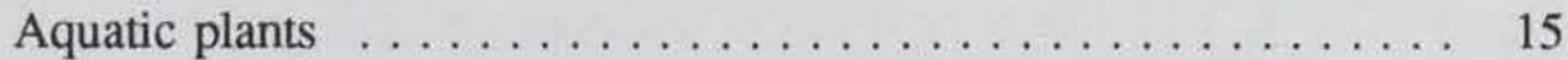

Greenhouse Studies . . . . . . . . . . . . . . . . . 31

Water quality of greenhouse tanks .............. 31

Sediment survey growth bioassay greenhouse experiment $\ldots \ldots \ldots 31$

Species survey growth bioassay greenhouse experiment $\ldots \ldots \ldots 35$

Onondaga Lake sediment seed bank . . . . . . . . . . . . . 40

4 Conclusions and Recommendations $\ldots \ldots \ldots \ldots \ldots \ldots . \ldots . \ldots . \ldots 4$

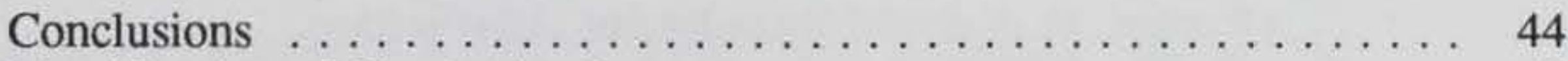

Identification of Continuing Issues $\ldots \ldots \ldots \ldots \ldots \ldots \ldots \ldots$

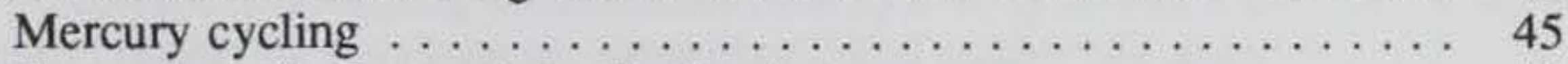

Expansion of current plant distributions . . . . . . . . . 45

Revegetation ..................... 45

Sediment composition and water quality improvements . . . . . . 45

Recommendations ....................... 46

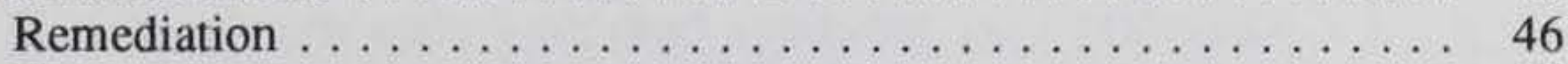

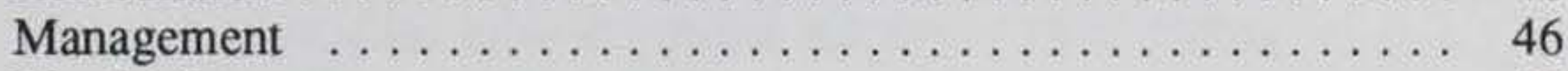

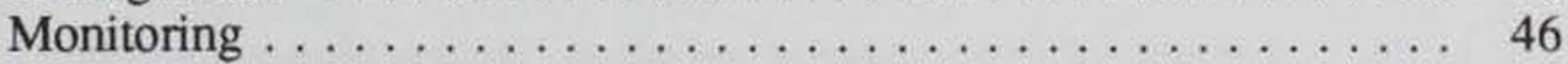

Research . . . . . . . . . . . . . . . . . 46

References .......................... 47

Appendix A: Voucher Specimens of Aquatic Macrophytes Taken from Onondaga

SF 298 


\section{List of Figures}

Figure 1. Location of vegetation survey transects in Onondaga Lake,

New York . . . . . . . . . . . . . . 7

Figure 2. Location of sediment cores in Onondaga Lake . . . . . . 8

Figure 3. Surficial littoral zone sediments of Onondaga

Lake . . . . . . . . . . . . . . . . . . . . . . . . . 14

Figure 4. Frequency of occurrence of the aquatic plant species

found in Onondaga Lake . . . . . . . . . . . . . . .

Figure 5. Depth distribution of aquatic plants in Onondaga Lake by frequency of occurrence $\ldots \ldots \ldots \ldots \ldots \ldots \ldots$

Figure 6. Depth distribution of aquatic plants in Onondaga Lake by average percent cover in quadrats where plants are found $\ldots \ldots \ldots \ldots \ldots \ldots \ldots \ldots \ldots \ldots \ldots \ldots \ldots \ldots \ldots \ldots \ldots$.

Figure 7. Percent of Onondaga Lake aquatic plants relative to sediment type . . . . . . . . . . . . . . .

Figure 8. Frequency distribution of aquatic plants in Onondaga Lake relative to sediment type $\ldots \ldots \ldots \ldots \ldots \ldots \ldots$

Figure 9. Aquatic plant species distribution in Onondaga

Lake ............................

Figure 10. Depth of colonization of aquatic macrophytes according to empirical relationships $\ldots \ldots \ldots \ldots \ldots \ldots \ldots$

Figure 11. $\mathrm{K}_{\mathrm{d}}$ and maximum depth of colonization calculated from attenuation coefficient . . . . . . . . . . . . . . .

Figure 12. Growth of Potamogeton pectinatus in greenhouse studies using Onondaga Lake sediments and a Lewisville reference sediment, by sediment source $\ldots \ldots \ldots \ldots \ldots \ldots \ldots$.

Figure 13. Growth of Potamogeton pectinatus in greenhouse studies using Onondaga Lake sediment mixtures and Lewisville reference, as analyzed by sediment classification . . . . . . .

Figure 14. Growth of Potamogeton pectinatus in greenhouse studies using Onondaga Lake sediments, as analyzed by origin from sites with high, medium, or low plant abundance . . . . . . .

Figure 15. Shoot nitrogen, shoot phosphorus, and shoot N:P ratio for Potamogeton pectinatus in greenhouse studies using Onondaga Lake sediments from three plant abundance groups from which the sediments were collected

Figure 16. Growth of Potamogeton pectinatus in greenhouse studies using Onondaga Lake sediments and Lewisville reference

Figure 17. Shoot weight of aquatic plant species grown in greenhouse conditions using Onondaga Lake oncolite, organic, and mixture sediments, and on a Lewisville reference . . . . . . . 
Figure 18. Root weight of aquatic plant species grown in greenhouse conditions using Onondaga Lake oncolite, organic, and mixture sediments, and on a Lewisville reference

Figure 19. Total plant weight of aquatic plant species grown in greenhouse conditions using Onondaga Lake oncolite, organic, and mixture sediments, and on a Lewisville reference

Figure 20. Seedling emergence from sand, oncolite, organic, and silt sediments from Onondaga Lake under greenhouse conditions

\section{List of Tables}

Table 1. Historical References to Aquatic Macrophyte Species in Onondaga Lake, Compared to Recent Finds from 1991

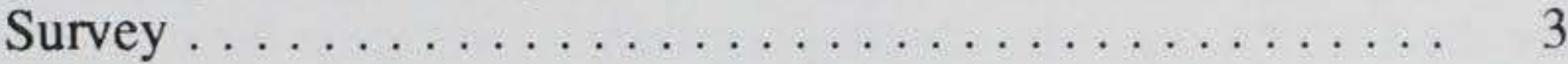

Table 2. Species Richness of Submersed, Floating-leaved, Emergent, and All Components of Littoral Zone Aquatic Plant Communities of Some New York Lakes . . . . . . . . . 4

Table 3. Laboratory Analytical Methods Utilized in Water, Sediment,

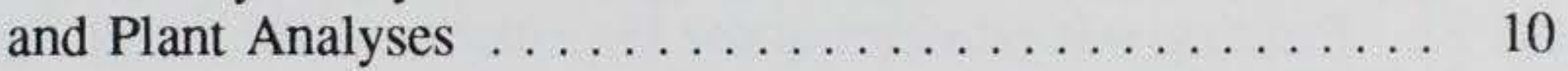

Table 4. Distribution of Surficial Sediments in the Littoral Zone of Onondaga Lake .................... 14

Table 5. Laboratory Analysis of Onondaga Lake Transect Sediment Samples and Samples Used in Greenhouse Experiments . . 16

Table 6. Algae and Macrophytes Present in Onondaga Lake . . . . . 17

Table 7. Aquatic Macrophyte Species List for Onondaga Lake, Nine Mile Creek, and Otisco Lake . . . . . . . . . . .

Table 8. Depth Distribution and Abundance of Macrophyte Species in Onondaga Lake at the 40 Survey Transects . . . . . . . .

Table 9. Tolerance Range of Some Tolerant Aquatic Macrophytes for Salinity, $\mathrm{Cl}^{-1}$, and Conductivity Levels in Fresh

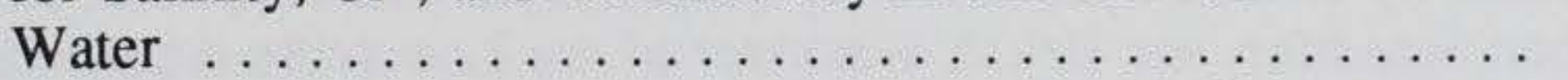

Table 10. Averages of Water Chemistry Parameters in Greenhouse Tanks at the Beginning and End of the Potamogeton pectinatus Trials and Species Survey Trials

Table 11. Performance of Eleven Species on Onondaga Lake Sediments 


\section{Preface}

The work reported herein was performed for the Onondaga Lake Management Conference (OLMC), Syracuse, NY, with support from the U.S. Environmental Protection Agency (USEPA) Region II through Intergovernmental Agreement No. DW96941541-01-0 with the U.S. Army Engineer Waterways Experiment Station (WES), Environmental Laboratory (EL), in cooperation with the New York State Department of Environmental Conservation and the Rensselaer Fresh Water Institute, Rensselaer Polytechnic Institute, Troy, NY. Project Officer for the USEPA was Mr. Robert Vaughn; Project Coordinator for the USEPA was Mr. Christopher Dere. Executive Director of the OLMC was Mr. Timothy Mulvey.

Publication of the report was funded by the Aquatic Plant Control Research Program (APCRP), which is sponsored by the Headquarters, U.S. Army Corps of Engineers (HQUSACE), and is assigned to the WES under the purview of the EL. Funding was provided under Department of the Army Appropriation No. 96X3122, Construction General. The APCRP is managed under the Environmental Resources Research and Assistance Programs (ERRAP), Mr. J. L. Decell, Manager. Mr. Robert C. Gunkel was Assistant Manager, ERRAP, for the APCRP. Technical Monitor during this study was Ms. Denise White, HQUSACE.

Principal Investigator for the study was Dr. R. Michael Smart, Ecosystem Processes and Effects Branch (EPEB), Environmental Processes and Effects Division (EPED), EL. The report was prepared by Dr. John D. Madsen of the EPEB, with contributions from Dr. Smart, Drs. Jay A. Bloomfield and James W. Sutherland of New York State Department of Environmental Conservation (Albany, NY), and Mr. Lawrence W. Eichler and Dr. Charles W. Boylen of Rensselaer Polytechnic Institute. Technical assistance at EPEB was provided by Keith Loyd, Kimberly Mauermann, Chetta Owens, Julia Scott, Nathan Standifer, and Bekah Westover of the Lewisville Aquatic Ecosystem Research Facility (LAERF). Robert Bombard and Tim Clear of Rensselaer Fresh Water Institute assisted at Onondaga Lake. Information was provided by Dr. Bruce Gilman, Community College of the Finger Lakes, Canandaigua, NY, and Dr. Steven Effler, Upstate Freshwater Institute, Syracuse, NY. The report was reviewed within EL by Drs. Kurt Getsinger and Robert Doyle of EPEB.

This investigation was performed under the general supervision of Dr. John Harrison, Director, EL; Mr. Donald L. Robey, Chief, EPED; and Dr. Richard E. Price, Acting Chief, EPEB.

At the time of publication of this report, Director of WES was Dr. Robert W. Whalin. Commander was COL Bruce K. Howard, EN. 
This report should be cited as follows:

Madsen, John D., Eichler, Lawrence W., Sutherland, James W., Bloomfield, Jay A., Smart, R. Michael, and Boylen, Charles W. (1993). "Submersed littoral vegetation distribution: Field quantification and experimental analysis of sediment types from Onondaga Lake, New York," Technical Report A-93-14, U.S. Army Engineer Waterways Experiment Station, Vicksburg, MS. 


\section{Introduction}

\section{The Problem}

Located at the northwestern edge of metropolitan Syracuse, NY, Onondaga Lake is 1,192 ha in area with a circumference of $18 \mathrm{~km}$. It once supported a productive warmwater and coldwater fishery that encouraged a thriving tourist trade during the late 1800 's. Since that time, municipal effluent and a large portion of the region's industrial waste have been discharging to Onondaga Lake, creating a severely polluted body of water (Effler 1987).

As a result of public health concerns related to the inflow of wastewater, Onondaga Lake was closed to swimming during the 1930's. By 1970, the inputs from an adjacent chlor-alkali facility had severely impacted Onondaga Lake; the water was supersaturated with calcium salts, the Secchi disk transparency was less than $1 \mathrm{~m}$, and the littoral zone was covered with precipitated calcium carbonate concretions, or oncolites (Saroff 1990; Effler 1992). By 1972, the consumption of fish from the Lake was prohibited as a result of mercury contamination of fish flesh (Effler et al. 1990).

Other examples of the highly degraded water quality of Onondaga Lake include high standing crops of phytoplankton (Field and Effler 1983), extended periods of hypolimnetic anoxia (Effler et al. 1986), a high rate of sedimentation (Effler 1987), severe degradation of the littoral zone with industrial deposits (Dean and Eggleston 1984), and contamination of the sediments with mercury (Effler 1987). Recently, Onondaga Lake was described as one of the most polluted lakes in the United States (U.S. Senate, Committee on Environment and Public Works 1989).

In addition to degraded water quality, Onondaga Lake is characterized by having few aquatic macrophytes. Aquatic macrophytes may be defined as plants that are visible to the naked eye, both vascular plants (flowering and nonflowering plants with water and food-conducting tissues) and nonvascular plants, such as the macroscopic algal charophytes. These species are predominantly rooted or attached to the sediment, although some free-floating forms exist (e.g., duckweed (Lemna sp.) and coontail (Ceratophyllum demersum). Aquatic macrophytes are classified as having emergent (i.e., extending out of the water), floating (i.e., floating on the surface of the water), or submersed (i.e., totally under water) leaves. The reader is directed to other sources for a 
more complete treatment of aquatic macrophyte taxonomy (Fassett 1957) and ecology (Wetzel 1983, Hutchinson 1975).

Aquatic macrophytes are an important constituent in lake ecosystems. They produce food for other aquatic organisms, serving as the base of an aquatic food chain; and also provide habitat areas for insects, fish of all age classes, and other resident aquatic and semi-aquatic organisms. Littoral zones, and the vegetation that structures them, are a prime area for the spawning of most fish species, including many species important to sport fisheries. Aquatic vegetation also serves to anchor soft sediments, stabilize underwater slopes, and remove suspended particles and nutrients from overlying waters. All of the above factors indicate the importance of natural littoral vegetation to the health of lake ecosystems.

The absence of littoral vegetation from a lake will result in reduced diversity and the loss of some important species, as well as reduced production of desirable fish species. Loss of vegetation may contribute to silt resuspension, turbidity, and increased algal productivity. In addition to the biological and ecosystem changes, loss of vegetation will result in reduced aesthetic and recreational value of a lake.

Little quantitative or observational data have been recorded for emergent, floating, or submersed aquatic macrophytes within Onondaga Lake, as noted in the Proceedings of the Onondaga Lake Remediation Conference (Saroff 1990). Anecdotal evidence suggested that the lake at one time, possibly as late as 1948, sustained extensive areas of charophytes, either Chara or Nitella. This is substantiated by the observation of charophyte stems at the core of oncolites (Dean and Eggleston 1984). Other macroscopic aquatic plants observed prior to 1991 were Potamogeton pectinatus (Stone and Pasko 1946), Myriophyllum spicatum, and Ceratophyllum demersum .

Historical species richness estimates for the lake are difficult to determine, and may have fluctuated even before any human influence. However, some of the historical references are summarized in Table 1. From the list compiled by McMullen (1991) 16 species are listed, although only 13 would definitely be found from the water's edge or deeper. Other species might possibly be added to this list; but the references are unclear and this is an attempt at a conservative listing. Two species can definitely be added to these 13 from voucher specimens at the State Museum Herbarium, bringing the total number of species to 15 . In addition, it has been conjectured, without the evidence of voucher specimens or authoritative eyewitnesses, that either or both of the macroalgae genera Chara or Nitella were common in the lake (Dean and Eggleston 1984). Historical records of species richness are consistent with observations of other New York lakes (Table 2).

Plant nutrition is an important factor controlling plant growth and survival. Alkalinity and inorganic carbon content, characteristics of the overlying waters, are one aspect of plant nutrition. Inorganic carbon is generally supplied to the plant by overlying water and varies with alkalinity and $\mathrm{pH}$. Inorganic carbon is an important building block to the plant. Most of the mineral nutrients 


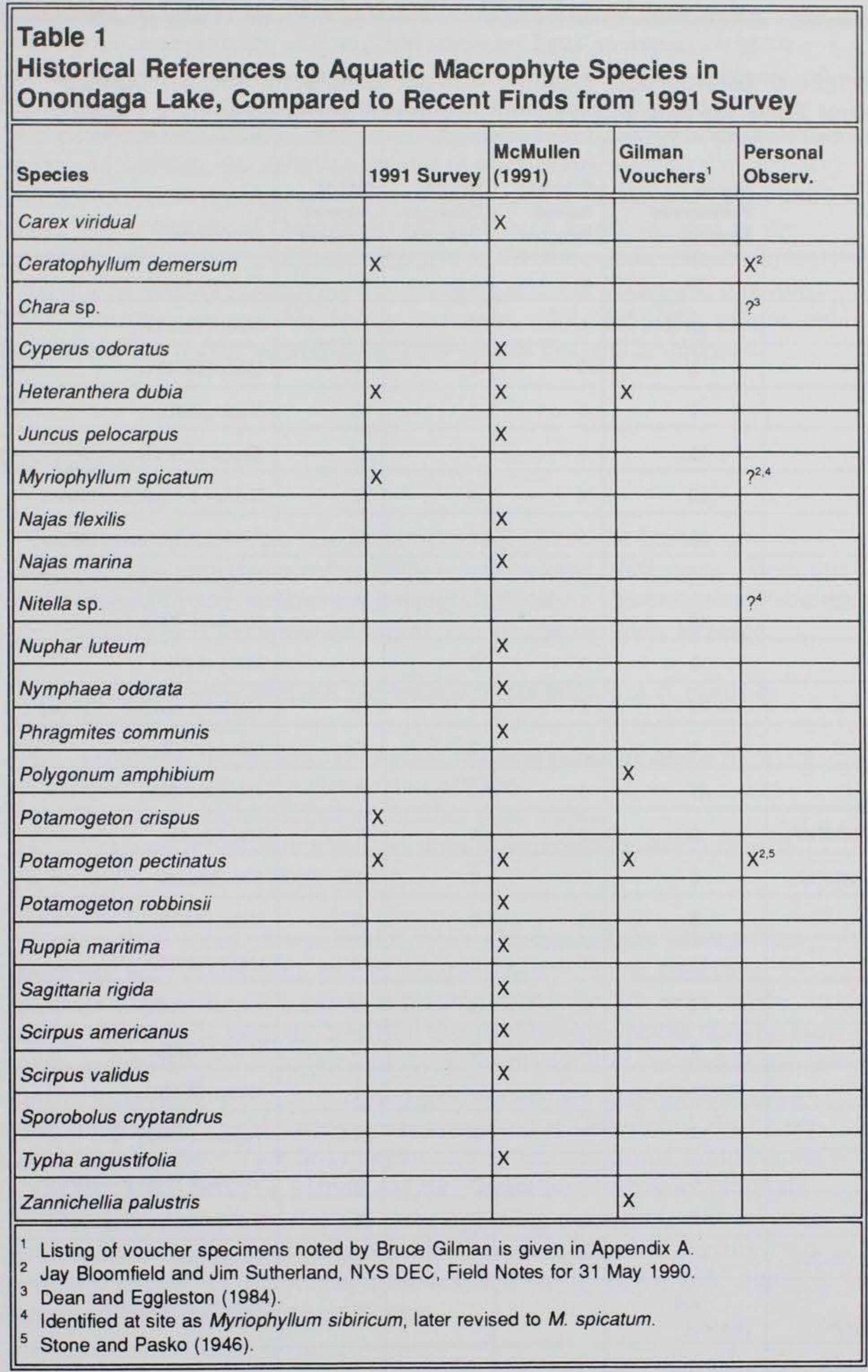




\begin{tabular}{|c|c|c|c|c|c|}
\hline Lake & $\begin{array}{l}\text { No. of } \\
\text { Submersed } \\
\text { Species }\end{array}$ & $\begin{array}{l}\text { No. of } \\
\text { Floating- } \\
\text { leaved } \\
\text { Species }\end{array}$ & $\begin{array}{l}\text { No. of } \\
\text { Emergent } \\
\text { Species }\end{array}$ & $\begin{array}{l}\text { No. of } \\
\text { Aquatic } \\
\text { Species }\end{array}$ & Reference \\
\hline Brant Lake & 29 & 4 & 5 & 38 & Eichler (1990) \\
\hline Cayuga Lake & 10 & 1 & 0 & 11 & Miller (1978) \\
\hline Cross Lake & 5 & 3 & 0 & 8 & Miller (1978) \\
\hline Duck Lake & 6 & 3 & 1 & 10 & Miller (1978) \\
\hline Eagle Lake (1988) & 19 & 2 & 1 & 22 & Taggett (1989) \\
\hline Eagle Lake (1989) & 23 & 2 & 3 & 28 & Eichler \& Madsen (1990c) \\
\hline Fourth Lake & 15 & 4 & 4 & 23 & Eichler \& Madsen (1990a) \\
\hline Galway Lake & 18 & 0 & 1 & 19 & Eichler \& Madsen (1990b) \\
\hline Honeoye Lake & 16 & 2 & 1 & 19 & Gilman (1985) \\
\hline Lake Como & 8 & 3 & 0 & 11 & Miller (1978) \\
\hline Lake Luzerne & 25 & 2 & 1 & 28 & Eichler \& Madsen (1990a) \\
\hline Little Sodus B & 8 & 9 & 2 & 19 & Miller (1978) \\
\hline Loon Lake & 21 & 4 & 6 & 31 & Taggett (1989) \\
\hline Onondaga Lake (Historical) & 9 & 3 & 8 & 20 & This Report \\
\hline Onondaga Lake (Current) & 5 & 0 & 0 & 5 & This Report \\
\hline Otter Lake & 5 & 3 & 0 & 8 & Miller (1978) \\
\hline Owasco Lake & 14 & 1 & 0 & 15 & Miller (1978) \\
\hline Paradox Lake & 12 & 3 & 4 & 19 & Taggett (1989) \\
\hline Parker Pond & 1 & 3 & 0 & 4 & Miller (1978) \\
\hline Skaneateles L. & 11 & 0 & 0 & 11 & Miller (1978) \\
\hline Schroon Lake & 18 & 1 & 2 & 21 & Taggett (1989) \\
\hline Second Lake & 22 & 4 & 4 & 30 & Eichler \& Madsen (1990a) \\
\hline Third Lake & 12 & 3 & 3 & 18 & Eichler \& Madsen (1990a) \\
\hline New York Average $(\mathrm{N}=23)$ & 13.6 & 2.6 & 2 & 18.2 & Above refs. \\
\hline $\begin{array}{l}\text { World Average } \\
\text { (Submersed, Eutrophic) }\end{array}$ & $\begin{array}{r}4.4 \\
(\mathrm{~N}=163) \\
\end{array}$ & - & - & - & Taggett et al. (1990) \\
\hline $\begin{array}{l}\text { World Average } \\
\text { (Submersed, Saline) }\end{array}$ & $\begin{array}{r}3.2 \\
(\mathrm{~N}=25) \\
\end{array}$ & - & - & - & Taggett et al. (1990) \\
\hline $\begin{array}{l}\text { World Average } \\
\text { (Submersed, all lakes) }\end{array}$ & $\begin{array}{r}6.6 \\
(\mathrm{~N}=439)\end{array}$ & - & - & - & Taggett et al. (1990) \\
\hline
\end{tabular}


are supplied by sediments. In addition to sediment nutrient content, the sediment texture, composition, and physical attributes have an impact on plant success. Sediments are the chief source of nutrients, particularly nitrogen and phosphorus, to aquatic vegetation (Barko and Smart 1981; Barko 1983), and the nutrient content of sediments is one important factor related to plant growth. In addition, the composition and physical characteristics (i.e., density) and organic matter content can influence plant growth (Barko and Smart 1983; 1986). The sediments of Onondaga Lake have been heavily altered by the deposition of oncolites, a calcium carbonate concretion, to the extent that most of the littoral zone is now covered by oncolitic material (Dean and Eggleston 1984). Oncolites are unstable, low in nutritional value, and highly porous, but the potential for littoral vegetation to grow on this material is unknown.

\section{Purpose}

The primary purpose for this project is to revegetate the littoral zone of Onondaga Lake, restoring a native littoral zone wetland community. Since this lake is unusual in both sediment and water chemistry, some preliminary studies were necessary to direct revegetation efforts. Secondary goals included:

- Elucidate environmental factors and limits to growth of plants in Onondaga Lake

- Determine the current distribution and abundance of plants in Onondaga Lake in a quantitative fashion

- Determine sediment factors limiting plant growth

- Evaluate potential remediation steps to improve the ability of sediments to support plant growth.

During 1991, a project was funded by the Onondaga Lake Management Conference with the ultimate goal of revegetating the littoral zone of Onondaga Lake with native plants to provide habitat for fish and wildlife. In order to achieve this goal, the first step was to determine factors limiting plant growth in the lake and experimentally manipulate plants in the greenhouse to improve growth. The project included field survey and experimental greenhouse components. Field surveys were conducted at Onondaga Lake by personnel from the New York State Department of Environmental Conservation's (NYSDEC) Lake Services Section and the Rensselaer Fresh Water Institute (RFWI). Experimental studies and bioassays using a greenhouse tank system were conducted at the Lewisville Aquatic Ecosystem Research Facility (LAERF), in Lewisville, TX, a satellite research facility of the U.S. Army Engineer Waterways Experiment Station.

During the 1991 field surveys, the littoral zone was surveyed for the distribution and abundance of submersed macrophyte species and the types of sediments that occur in this region. The littoral zone sediment types were evaluated by plant growth bioassay at the LAERF to (1) determine the potential of Onondaga Lake sediments for supporting plant growth, (2) determine the effectiveness of some possible sediment remediation steps, such as 
sediment amendments or mixtures, and (3) examine some of the potential species to be found in Onondaga Lake, either native species desirable for revegetation efforts or exotic species that might colonize the lake. 


\section{Materials and Methods}

\section{Field Studies}

The distribution of submersed littoral vegetation in Onondaga Lake was examined using 40 transects placed in a stratified-random manner around the lake (Figure 1). The shoreline of the lake was divided into 40 equal segments, or strata, and a single transect was located randomly within each segment. Transects were placed perpendicular to the shoreline. Each transect was divided into $1001-\mathrm{m}$ segments and a $0.1-\mathrm{m}^{2}$ quadrat was placed at each

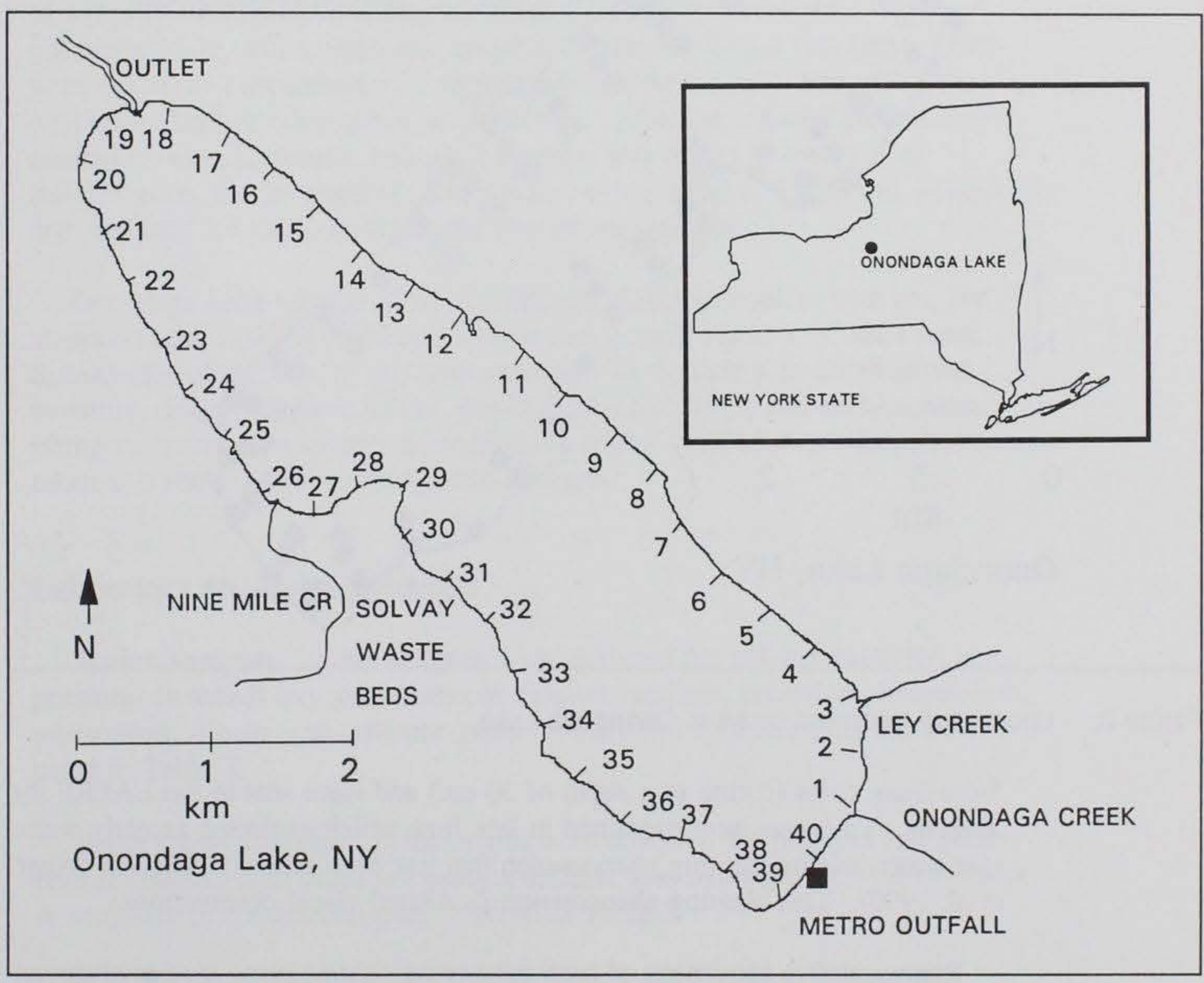

Figure 1. Location of vegetation survey transects in Onondaga Lake, New York 
1-m interval. Abundance (e.g., percent cover) of each species within each quadrat was estimated based on a Daubenmire scale (Daubenmire 1959; 1968) by SCUBA divers knowledgeable in aquatic plant identification (Madsen et al. 1989). In addition, surficial sediment type and water depth of each quadrat were recorded. Transects began at the shoreline and extended out into the lake $100 \mathrm{~m}$ or to a depth of $3 \mathrm{~m}$, reflecting the extent of the littoral zone. Several transects were extended to a depth of $7 \mathrm{~m}$ to assure coverage of that zone.

Sediment classification was made visually for each quadrat, with core samples collected to standardize observations by particle size analysis and other physical parameters. Standardization utilized representative samples from each transect, with 1 to 3 sediment core samples taken per transect (Figure 2). Ninety-four sediment core samples were collected by divers using

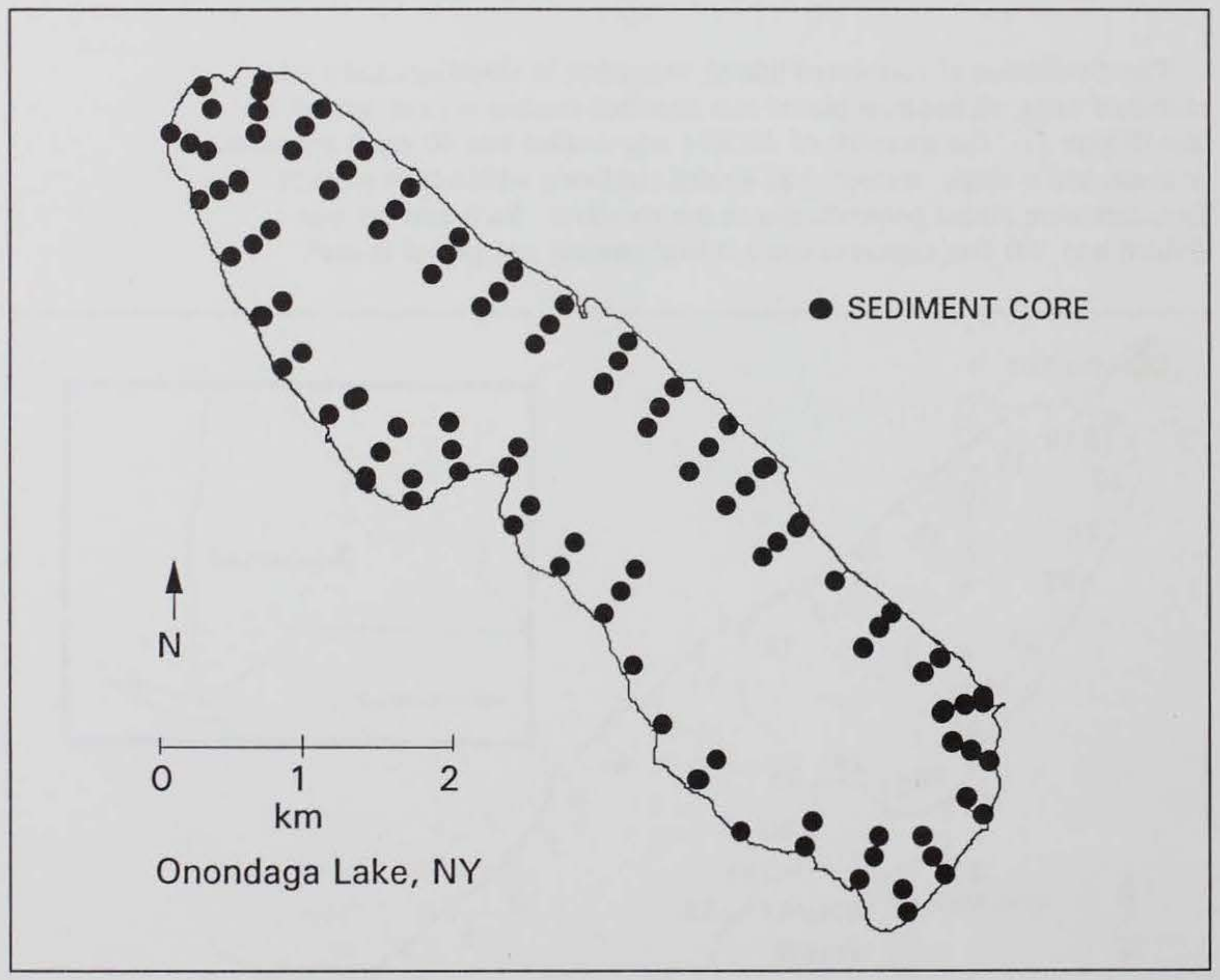

Figure 2. Location of sediment cores in Onondaga Lake

5-cm diam cores (coring to a depth of $30 \mathrm{~cm}$ ) and were sent to the LAERF for analysis. Transects were examined in late June which exploited an early summer water-column-clearing phenomenon that has been recently observed (Auer et al. 1990). This clearing phenomenon facilitated visual observations.

Representative specimens of each submersed aquatic plant species observed were collected and returned to the RFWI facility in Bolton Landing, NY, 
where they were mounted and preserved in a herbarium to provide a permanent record.

Visual observations were used to divide the sediments into categories or "types," including gravel, oncolite, sand, silt, and carbonate as well as mixtures of these types. A sketch map of these sediment categories was generated. Based on this information, locations were chosen to provide sediments for greenhouse studies.

\section{Greenhouse Studies}

\section{General experimental setup}

Experimental studies were conducted using 20 large $(1,200 \ell)$ growth tanks ( $95 \mathrm{~cm}$ wide by $155 \mathrm{~cm}$ long by $85 \mathrm{~cm}$ wide) in a greenhouse at the LAERF. Filtered lake or well water was used in these tanks, which was further amended with $220 \mathrm{~g}$ of $\mathrm{CaCl}_{2}$ to correspond to the current chemical composition of Onondaga Lake. Water temperature was maintained at $25 \pm 2{ }^{\circ} \mathrm{C}$. Ambient light conditions in the greenhouse were utilized without amendment of intensity or daylength, and approximated $50 \%$ of full sunlight. Water chemistry, light, and temperature conditions were monitored regularly. Plants were grown in $1-\ell$ containers of experimental sediment, with two plants per container. Each treatment had six replicates. After the allowed growth period, containers were harvested, and plant material was sorted to root, shoot, inflorescence, and propagules. Plant material was dried at $55^{\circ} \mathrm{C}$ and weighed and analyzed for tissue nitrogen and phosphorus content.

Onondaga Lake sediments were collected, placed in coolers with ice, and shipped to the LAERF. Sediments were then stored wet at $4{ }^{\circ} \mathrm{C}$ until used. Subsamples of each sediment were examined for particle size distributions, moisture, density, organic matter, physical characteristics, and exchangeable nitrogen. After the experiment, sediment samples from each container were taken and analyzed for exchangeable nitrogen.

\section{Laboratory analytical methods}

Water analyses. Water samples were analyzed for $\mathrm{pH}$, conductivity, temperature, dissolved oxygen, alkalinity, calcium, sodium, potassium, magnesium, ammonium, nitrate, and orthophosphate. Analytical methods used are indicated in Table 3.

Plant tissue analyses. Plant tissues were analyzed for nitrogen and phosphorus content, after digestion using a sulfuric acid-hydrogen peroxide method. A summary of these techniques is given in Table 3 . 


\begin{tabular}{|c|c|c|}
\hline \multicolumn{3}{|c|}{$\begin{array}{l}\text { Table } 3 \\
\text { Laboratory Analytical Methods Utilized in Water, Sediment, ano } \\
\text { Plant Analyses }\end{array}$} \\
\hline Analysis & Method/Instrument & Reference \\
\hline \multicolumn{3}{|c|}{ Water Analysis } \\
\hline Alkalinity & Electrometric titration & APHA et al. (1989) \\
\hline $\mathrm{pH}$ & Electrometric & APHA et al. (1989) \\
\hline Ammonia- $\mathrm{N}$ & Specific-ion electrode & APHA et al. (1989) \\
\hline Nitrate- $\mathrm{N}$ & Cadmium reduction & APHA et al. (1989) \\
\hline $\begin{array}{l}\text { Soluble Reactive } \\
\text { Phosphorus (SRP) }\end{array}$ & Ascorbic Acid Method & APHA et al. (1989) \\
\hline Sodium & AA - Spectrometric & APHA et al. (1989) \\
\hline Potassium & $A A$ - Spectrometric & APHA et al. (1989) \\
\hline Magnesium & $A A$ - Spectrometric & APHA et al. (1989) \\
\hline Calcium & AA - Spectrometric & APHA et al. (1989) \\
\hline \multicolumn{3}{|c|}{ Plant Tissue Analysis } \\
\hline Digestion - $\mathrm{N}$ and $\mathrm{P}$ & Sulfuric Acid/Hydrogen Peroxide & Allen et al. (1974) \\
\hline Nitrogen & Specific-ion electrode & APHA et al. (1989) \\
\hline Phosphorus & Ascorbic Acid Method & APHA et al. (1989) \\
\hline \multicolumn{3}{|c|}{ Sediment Analysis } \\
\hline Particle Size Analysis & Hydrometer (settling) & Day (1956) \\
\hline Moisture/Density & Gravimetric & APHA et al. (1989) \\
\hline Organic Matter Content & Combustion at $550^{\circ} \mathrm{C}$ & APHA et al. (1989) \\
\hline $\mathrm{CaCO}_{3}$ Content & Combustion at $950^{\circ} \mathrm{C}$ & APHA et al. (1989) \\
\hline Extraction $(\mathrm{N})$ & $\mathrm{NaCl}$ Extraction & Bremner (1965) \\
\hline Nitrogen & Specific-ion electrode & APHA et al. (1989) \\
\hline
\end{tabular}

Sediment analyses. Sediments were analyzed for particle size distribution, percent moisture, density, percent organic matter, percent calcium carbonate, and extractable nitrogen. The methods used are summarized in Table 3.

\section{Sediment bioassay--survey}

Sediments collected from nine (9) sites in the lake were evaluated as to their plant growing potential, with sago pondweed as the study species. Sediments were selected based on the relative abundance of plant material at the field survey transects $(\mathrm{T})$ : 
- High abundance (Mean Cover 32\%): T-39, T-19, T-14

- Medium abundance (Mean Cover 9\%): T-22, T-9, T-30

- Low abundance (Mean Cover 0.001\%): T-7, T-23, T-38

A locally available fertile sediment (Lewisville) was also used as a reference to potential plant growth. Replicates were randomly assigned to tanks. The growing period for these experiments was 6 weeks.

\section{Sediment bloassay--sediment types}

In the spring, field reconnaissance of lake sediments was conducted to find sources of four types of Onondaga Lake sediments: oncolites, organic silt, exposed silt, and exposed sand ("exposed" being not covered by oncolites). A locally obtained source of Lake Lewisville silty sediments was also used. The following mixtures, prepared on a volume basis, were evaluated:

- $\quad$ Oncolite (T-11)

- $\quad$ Organic (T-20)

- $\quad$ Sand (T-3)

- $\quad$ Silt (T-40)

- $\quad$ Lewisville (LWL)

- $\quad$ 1:1 Oncolite/Sand

- 1:1 Oncolite/Organic

- 1:1 Oncolite/Silt

- 1:1 Oncolite/Lewisville

Trials of the unmixed and mixed sediments were conducted during the same time period as that of the sediment survey bioassay, with replicates of all combinations randomly allocated to tanks with 18 containers per tank. The growing period for these experiments was 6 weeks.

\section{Sediment/species bioassays}

The growth of potential Onondaga Lake colonizers or choices for direct replanting were evaluated by examining the growth of these species on Onondaga Lake oncolites, Onondaga Lake organic, a 1:1 mixture of Onondaga Lake oncolite and organic, and the Lewisville (e.g., locally available fertile) reference. Six replicates of each sediment and species treatment were used. Six native and three exotic plant species were selected:

- Potamogeton pectinatus L. (sago pondweed) PP

- Potamogeton crispus L. (curly-leaf pondweed) EXOTIC PC

- Vallisneria americana Michx. (water celery) VA

- Myriophyllum spicatum L. (Eurasian watermilfoil) MS EXOTIC

- Elodea canadensis Michx. (elodea) EC

- Trapa natans L. (waterchestnut) EXOTIC TN

- Potamogeton nodosus L. (American pondweed) PN 
- Typha latifolia L. (cattail) TL

- Sagittaria latifolia Willd. (arrowhead) SL

The native species sago pondweed and water celery were chosen in that they are excellent candidates for revegetation due to their propagules, they are used at other locations for revegetation efforts, and they occur in abundance throughout that region of New York State. Waterchestnut, curly-leaf pondweed, and Eurasian watermilfoil are common exotic, nuisance species in that region, and as such are likely to colonize Onondaga Lake. Arrowhead and cattail were selected as emergent wetland species that could be tested for remediating wetland sites and are potential candidates for wetland transplants. The two emergent species were tested in a shallower tank (depth $=40 \mathrm{~cm}$ ) than the other species. In addition to the above tests, Sagittaria rigida Pursh. (rigid-leaf arrowhead; SR) and Nymphaea odorata Ait. (white water lily; NO) were tested on Onondaga Lake oncolites and Lewisville reference sediments. The growing period for these experiments was 8 weeks.

\section{Seed bank studies}

Four Onondaga Lake sediments were examined for the species composition and abundance of their seedbank. Sediments tested were:

- $\quad$ Sand (T3)

- Oncolite (T11)

- $\quad$ Organic (T20)

- $\quad$ Silt (T40)

Twenty replicates of each sediment type were examined for 12 weeks, by spreading sediments in a $40-\mathrm{cm}$ by $25-\mathrm{cm}$ tray to a depth of $2 \mathrm{~cm}$. Seedlings were marked as they emerged, and allowed to grow until species identifications were possible. Total number of seedlings emerged were calculated from this marking data. 


\section{Results and Discussion}

\section{Field Studies}

\section{Surficial sediments}

Visual observations of the surficial sediments of the littoral zone were recorded at 1-m intervals on each of the 40 transects used for aquatic plant evaluation. Results of the visual observations were then extrapolated to approximate the areal extent of the sediment types within the survey area (Figure 3, Table 4). A total of 3,497 discrete observations were recorded. Sediments were divided into 5 categories; gravel, sand, oncolite, silt and carbonate. Cores were collected from each transect for later physical and chemical analysis of sediments. Carbonate sediments were those composed of fine particlesize precipitates forming a thick crust, often around a colored fluid.

Gravel sediments consisted of coarse materials occurring in the wave zone within a few meters of the water mark. Gravel sediments were also common adjacent to the Metro outfall (transect 40). These areas can be characterized as areas of moderate to high levels of wave energy. The majority of gravels were observed on the northeast side of the lake, extending from transect 1 through transect 25 (see Figure 1). Gravels were recorded in 194 of the 3,497 quadrats, a frequency of $6 \%$. The areal extent of gravel sediments included $12.5 \mathrm{ha}$, or $7.8 \%$ of the area of the study zone.

Sediments were classified as oncolite if oncolites were readily identifiable; however, sediments classified as sand may have had some oncolites present. Sand and oncolite sediments covered $65 \%$ of the total area surveyed (103.6 ha of a total of $160 \mathrm{ha}$ ). Sand without oncolites covered $29.8 \mathrm{ha}$ ( $18.6 \%$ of the survey area) and generally was observed at the southeast margin of the lake. Sand with oncolites was found at 73.8 ha $(46.1 \%$ of the survey area). Sand and oncolite sediments were observed from the southeastern end of the lake along the eastern shore and at the northwest end. Transects 1 through 25 (see Figure 3 ) were dominated by sand and oncolite mixtures.

Silt, soft fine-grained sediments, were observed primarily on the southwestern shoreline and in the area just north of the Solvay waste beds. These areas are represented by transects $19,21,26,27,28,32,34,36,39$, and 40 . 


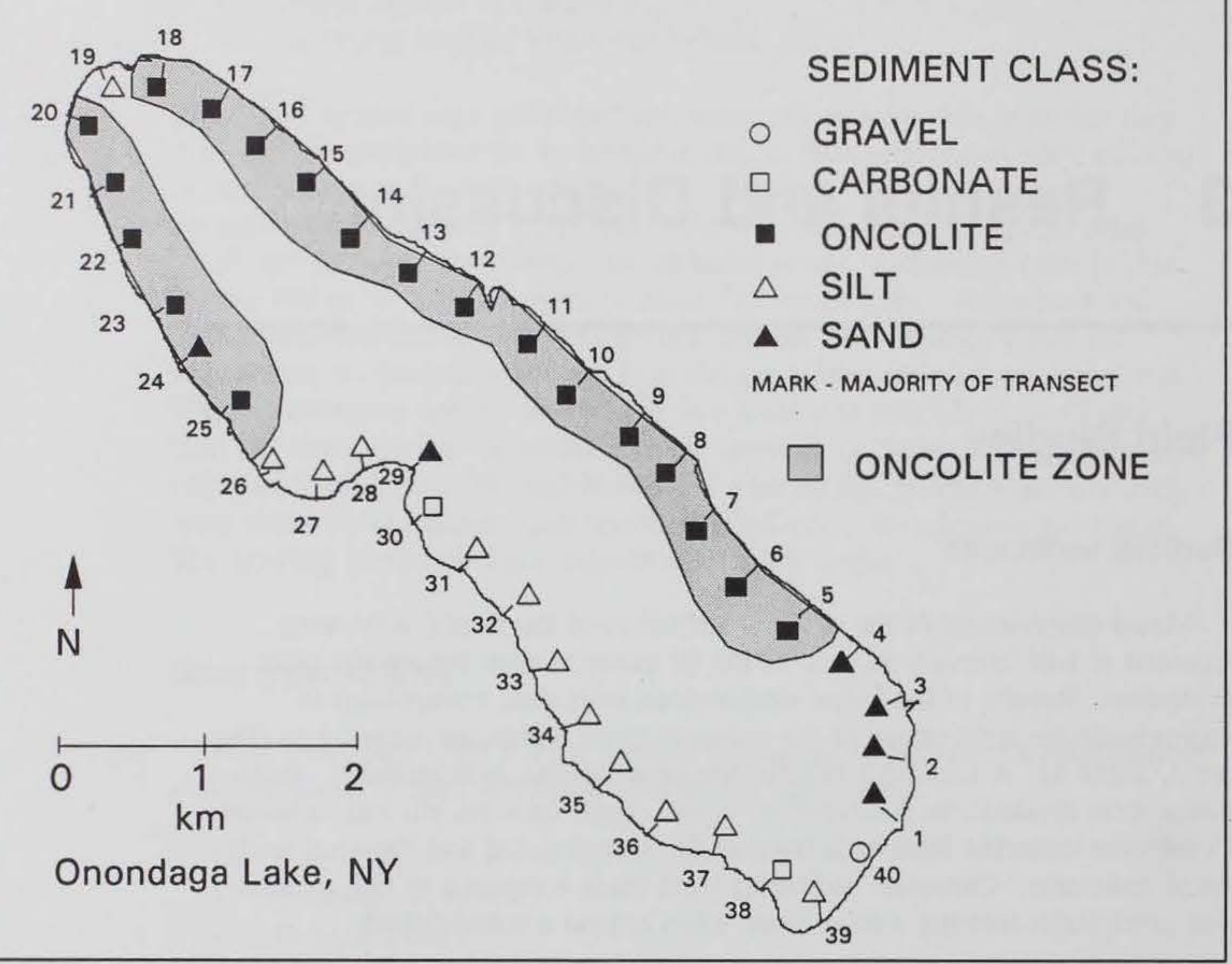

Figure 3. Surficial littoral zone sediments of Onondaga Lake

\begin{tabular}{|c|c|c|c|c|}
\hline \multicolumn{5}{|c|}{$\begin{array}{l}\text { Table } 4 \\
\text { Distrlbution of Surficlal Sediments in the Littoral Zone of } \\
\text { Onondaga Lake }\end{array}$} \\
\hline Sediment Type & Transects & $\begin{array}{l}\text { No. of } \\
\text { Quadrats }\end{array}$ & $\begin{array}{l}\text { No. of } \\
\text { Hectares }\end{array}$ & Percent \\
\hline Oncolite & 21 & 1,677 & 73.8 & 46.2 \\
\hline Silt & 10 & 572 & 35.5 & 22.2 \\
\hline Sand & 15 & 647 & 29.8 & 18.6 \\
\hline Gravel & 26 & 194 & 12.5 & 7.8 \\
\hline Carbonates & 7 & 407 & 8.4 & 5.2 \\
\hline TOTAL & 40 & 3,497 & 160.0 & 100.0 \\
\hline
\end{tabular}


Silts were recorded for $572(16 \%)$ of the quadrats surveyed. In areal extent, silts covered 35.5 ha $(22 \%)$ of the survey zone.

Sediments defined as carbonates were semisolid chalky materials covered with a thin layer of silt. Cores in these areas indicated stratified, deeper chalky sediments with bluish colors and occasional layers of black oily materials. Carbonate-dominated sediments were found at transects $30,31,33,35$, 37, and 38. Carbonate sediments were found at $407(12 \%)$ of the quadrats surveyed. In areal extent, 8.4 hectares of the survey zone $(5.2 \%)$ consisted of carbonate sediments.

Black oily deposits and petrochemical odors were associated with a number of sediment cores and were generally present as strata within the cores. The position of the strata relative to the surface of the sediments was variable. Cores with petrochemical odors were collected from the southwestern margin of the lake at transects 2, 26, 27, 31, 32, 34, 35, 37, 39, and 40. Specimens of these oily deposits were provided to the NYS Department of Environmental Conservation for later analysis.

Laboratory analyses of transect sediments indicated that Onondaga Lake sediments are low in organic matter and high in $\mathrm{CaCO}_{3}$ (Table 5). Onondaga Lake sediments that were higher in organic matter were those contaminated with the black oily deposits described above. Particle size distribution in these samples was not unusual for lacustrine sediments.

\section{Aquatic plants}

The distribution of submersed littoral vegetation was surveyed between 24 and 26 June 1991. Five species of submersed macrophytes were found in Onondaga Lake (Table 6). Three genera of filamentous algae were also observed attached to hard substrates, e.g. gravel, timber, debris (Table 6).

The major species in order of frequency of occurrence based on all of the quadrats used for percent cover determinations were Potamogeton pectinatus (11.2\% of quadrats), Heteranthera dubia (1.8\%), Ceratophyllum demersum $(0.3 \%)$, Potamogeton crispus $(0.3 \%)$ and Myriophyllum spicatum $(0.06 \%)$. Of the 465 quadrats where plants were observed (13.3\% of quadrats surveyed), Potamogeton pectinatus was the dominant species occurring at 391 (84\%) of the quadrats (Figure 4).

The depth distribution of these five species in shown in Figure 5, based on frequency of occurrence in all quadrats. Potamogeton pectinatus was present from 0 - to 2-m depth; however, it was substantially more abundant in the 0 - to 1 -m depth interval. Heteranthera dubia was present from 0 - to 5-m depth, the most extensive depth distribution of any species. This species reached its greatest abundance in the 1 - to $2-\mathrm{m}$ depth interval. The remaining three species were relatively rare but reached greatest abundance in depths of 0 to $2 \mathrm{~m}$. Potamogeton pectinatus was clearly the dominant species in the 0 - to 2-m depth range. This species frequently occurred in dense beds in water depths 


\begin{tabular}{|c|c|c|c|c|c|c|}
\hline \multicolumn{7}{|c|}{$\begin{array}{l}\text { Table } 5 \\
\text { Laboratory Analysis of Onondaga Lake Transect Sediment } \\
\text { Samples and Samples Used in Greenhouse Experiments }\end{array}$} \\
\hline $\begin{array}{l}\text { Transect/ } \\
\text { Classific. }\end{array}$ & $\begin{array}{l}\text { \%Organic } \\
\text { Matter }\end{array}$ & $\begin{array}{l}\text { \%Calcium } \\
\text { Carbonate }\end{array}$ & $\begin{array}{l}\text { Extrac. } N \\
\left(\mathrm{mg} \mathrm{g}^{-1}\right)\end{array}$ & \%Sand & \%Silt & \%Clay \\
\hline 1 & 2.81 & 26.3 & 4 & 56 & 26 & 18 \\
\hline 2 & 7.04 & 25.0 & 4 & 75 & 12 & 13 \\
\hline 3 (SAN) & 2.7 & 60.0 & 2 & 87.5 & 0 & 12.5 \\
\hline 4 & a & a & 2 & a & a & a \\
\hline 5 & a & a & 2 & a & $\mathrm{a}$ & $a$ \\
\hline 6 & 3.22 & 80.4 & 2 & 80 & 12.5 & 7.5 \\
\hline 7 & 2.66 & 69.9 & 2 & 90 & 0 & 10 \\
\hline 8 & 3.78 & 79.0 & 2 & 67.5 & 27.5 & 5 \\
\hline 9 & 2.65 & 60.0 & 2 & 85 & 2.5 & 12.5 \\
\hline 10 & $a$ & a & 3 & 97.5 & 0 & 2.5 \\
\hline 11 (ONC) & 2.82 & 60.0 & 3 & 97.5 & 2.5 & 0 \\
\hline 12 & $\mathrm{a}$ & a & 1 & $a$ & a & $a$ \\
\hline 13 & 2.87 & 68.4 & 1 & 84 & 7.5 & 8.5 \\
\hline 14 & 1.49 & 33.4 & 1 & 88 & 6 & 6 \\
\hline 15 & 2.90 & 78.9 & 1 & 65 & 25 & 10 \\
\hline 16 & a & a & 2.5 & 55 & 40 & 5 \\
\hline 17 & 3.08 & 57.8 & 3 & 85 & 5 & 10 \\
\hline 18 & 4.15 & 68.5 & 2 & 90 & 6 & 4 \\
\hline 19 & 3.01 & 82.3 & 2 & 92.5 & 4 & 4.5 \\
\hline 20 (ORG) & 3.72 & 85.4 & 9 & 85 & 0 & 15 \\
\hline 21 & a & a & 1 & 76 & 15 & 9 \\
\hline 22 & 4.17 & 86.3 & 1 & 95 & 5 & 0 \\
\hline 23 & a & a & 1 & 86 & 11 & 3 \\
\hline 24 & $a$ & a & 2 & 77.5 & 17.5 & 5 \\
\hline 25 & 3.96 & 84.0 & 2 & 85 & 0 & 15 \\
\hline 26 & a & a & 2 & 51 & 37 & 12 \\
\hline 27 & $a$ & a & 16 & 25 & 61 & 14 \\
\hline 28 & $a$ & a & 3 & 85 & 7.5 & 7.5 \\
\hline 29 & 1.35 & 32.8 & 2 & 82.5 & 5 & 12.5 \\
\hline
\end{tabular}




\begin{tabular}{|c|c|c|c|c|c|c|}
\hline $\begin{array}{l}\text { Transect } \\
\text { Classific. }\end{array}$ & $\begin{array}{l}\text { \%Organic } \\
\text { Matter }\end{array}$ & $\begin{array}{l}\% \text { Calcium } \\
\text { Carbonate }\end{array}$ & $\begin{array}{l}\text { Extrac. } \mathrm{N} \\
\left(\mathrm{mg} \mathrm{g}^{-1}\right)\end{array}$ & $\%$ Sand & $\%$ Silt & \%Clay \\
\hline 31 & a & $\mathrm{a}$ & 6 & 60 & 32.5 & 7.5 \\
\hline 32 & 10.4 & 65.6 & 2 & 36 & 63 & 1 \\
\hline 33 & 9.14 & 63.2 & & 27.5 & 72.5 & 0 \\
\hline 34 & 13.2 & 33.3 & 1 & 47.5 & 40 & 12.5 \\
\hline 35 & 8.69 & 60.8 & 2 & 54 & 38 & 8 \\
\hline 36 & $\mathrm{a}$ & a & 1 & a & a & a \\
\hline 37 & 6.99 & 72.3 & 2 & 68 & 26 & 6 \\
\hline 38 & 8.26 & 66.8 & 1 & 70 & 22.5 & 7.5 \\
\hline 39 & 3.64 & 39.8 & 4 & 82.5 & 5 & 12.5 \\
\hline 40 (SIL) & 1.65 & 19.3 & 2 & 90 & 0 & 10 \\
\hline LWL & 8.64 & 3.7 & a & 45 & 27.5 & 27.5 \\
\hline $\begin{array}{l}T 11+L W L \\
(O N C+L W L) \\
\end{array}$ & 5.29 & 33.0 & a & 70 & 17.5 & 12.5 \\
\hline $\begin{array}{l}\text { T11+T20 } \\
\text { (ONC+ORG) } \\
\end{array}$ & 2.78 & 67.9 & a & 97.5 & 2.5 & 0 \\
\hline $\begin{array}{l}\text { T11+T3 } \\
\text { (ONC+SAN) }\end{array}$ & 2.76 & 57.5 & a & 80 & 5 & 15 \\
\hline $\begin{array}{l}\mathrm{T} 11+\mathrm{T} 40 \\
(\mathrm{ONC}+\mathrm{SIL})\end{array}$ & 1.83 & 33.0 & a & 85 & 0 & 15 \\
\hline
\end{tabular}

\begin{tabular}{||l|l||}
\hline $\begin{array}{l}\mid \text { Table } 6 \\
\text { Algae and Macrophytes Present in Onondaga Lake }\end{array}$ \\
\hline \hline Scientific Name & Common Name \\
\hline \hline Cladophora spp. & Green alga \\
\hline Closterium spp. & Green alga \\
\hline Pediastrum spp. & Green alga \\
\hline Ceratophyllum demersum & Coontail \\
\hline Heteranthera dubia & Water stargrass \\
\hline Myriophyllum spicatum & Eurasian watermilfoil \\
\hline Potamogeton crispus & Curly-leaf pondweed \\
\hline Potamogeton pectinatus & Sago pondweed \\
\hline
\end{tabular}




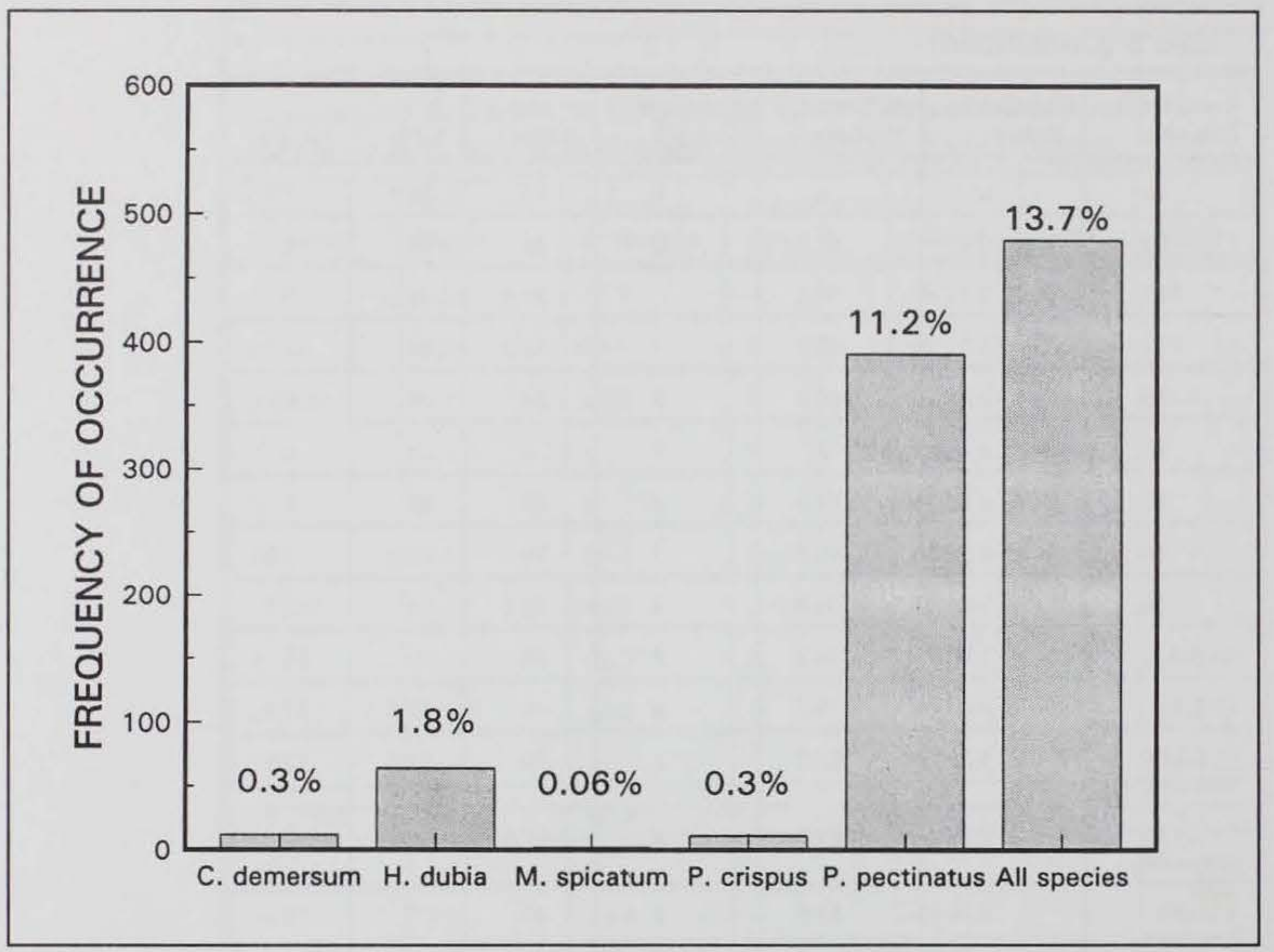

Figure 4. Frequency of occurrence (out of a total of 3,498 quadrats) of the aquatic plant species found in Onondaga Lake

of from 0.3 to $1 \mathrm{~m}$. Occasional beds of Heteranthera dubia were observed at the deep margin of beds of Potamogeton pectinatus. Beyond a depth of $2 \mathrm{~m}$ the distribution of all plants was limited. Abundance of each species in the quadrats where they occurred is presented in Figure 6. This figure indicates that, where found, Potamogeton pectinatus tends to form dense colonies.

Heteranthera dubia is occasionally found as denser stands, but often is also found as individual plants. The other species were only found as scattered plants, never in any great abundance.

As with abundance, the diversity of submersed macrophyte species varied with depth. All five species observed in Onondaga Lake were present in depths of 0 to $2 \mathrm{~m}$. In water depths of between 2 and $3 \mathrm{~m}$, only Heteranthera dubia and Ceratophyllum demersum were observed and beyond a depth of $3 \mathrm{~m}$, only Heteranthera dubia was still present.

Sediment characteristics play a major role in the distribution of aquatic plants within Onondaga Lake. Figure 7 shows the frequency of occurrence of aquatic plants related to each of the five sediment types recorded. Gravel sediments were least likely to support aquatic plant populations, followed closely by oncolite-dominated sediments. With the exception of areas of 


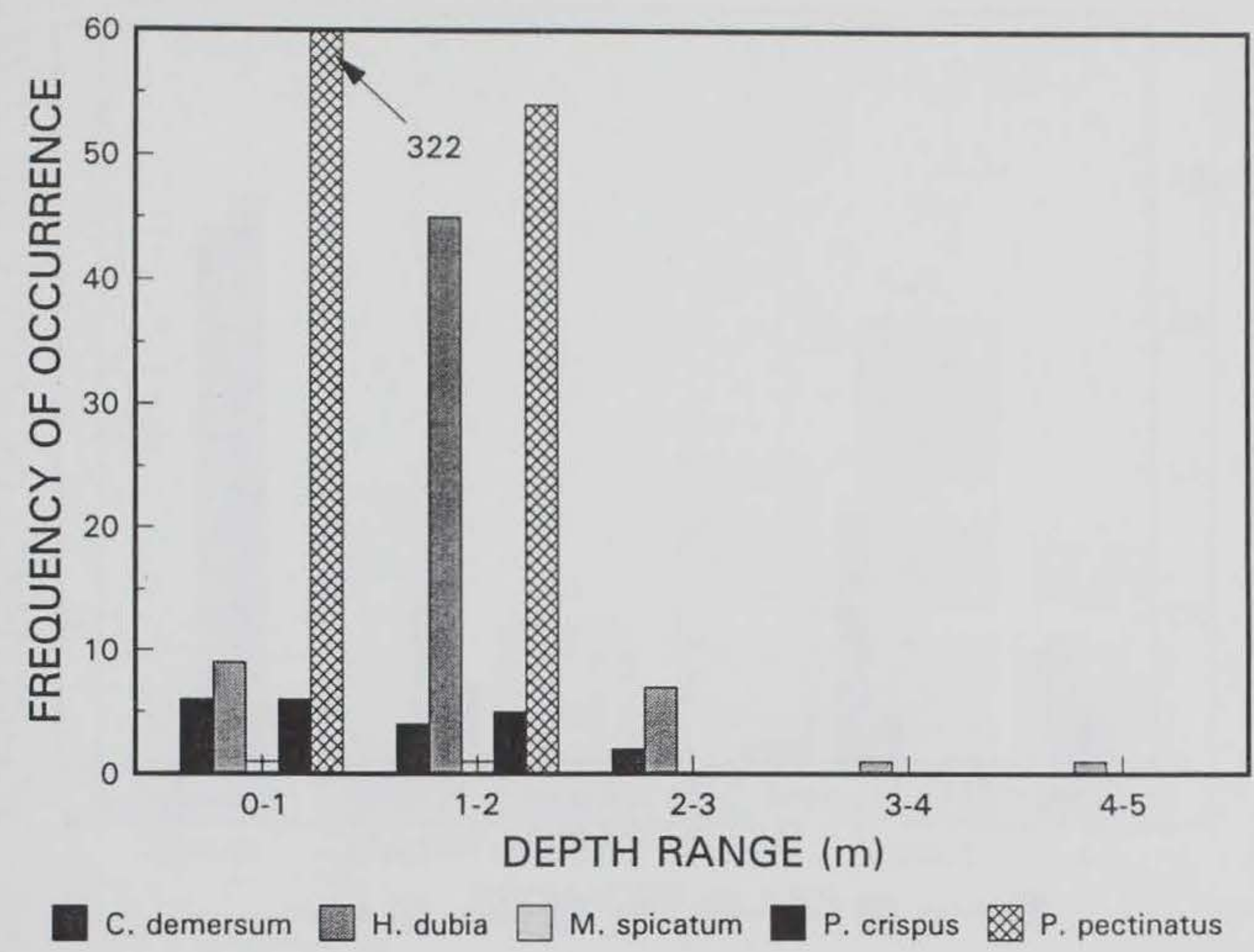

Figure 5. Depth distribution of aquatic plants in Onondaga Lake by frequency of occurrence: PP, Potamogeton pectinatus; PC, P. crispus; MS, Myriophyllum spicatum; HD, Heteranthera dubia; CD, Ceratophyllum demersum

transect 40 , all gravel sediments were found at the waters edge, where waveinduced turbulence and water level changes combine to severely limit aquatic plant growth. Sand, silt, and carbonate type sediments were more likely to support plant populations with from 18 to $21 \%$ of quadrats containing at least one plant. A comparison of the frequency of the different species to sediment types is presented in Figure 8. Potamogeton pectinatus occurred in all sediment types, but occurred significantly less often on oncolites and gravel than other substrates. On oncolite-dominated sediments, Potamogeton pectinatus and Heteranthera dubia were equally likely to occur. All other species had very limited distributions with no apparent relation to sediment type. These analyses indicate that plants have difficulty in establishing and remaining on oncolite sediments, with fewer problems establishing on other sediment types. It may be that oncolites, like the gravel sediments, are highly disturbed from wave action, or more prone to instability due to lower density. However, plants can occur in dense patches and, as seen in the greenhouse experiments, can grow to the same abundance on oncolites as on the other sediment types of Onondaga Lake.

Five species of submersed macrophytes were observed in Onondaga Lake (Table 7). Interestingly, no species of either floating-leaved or emergent plants were observed, growth forms typical of the transition from the littoral 


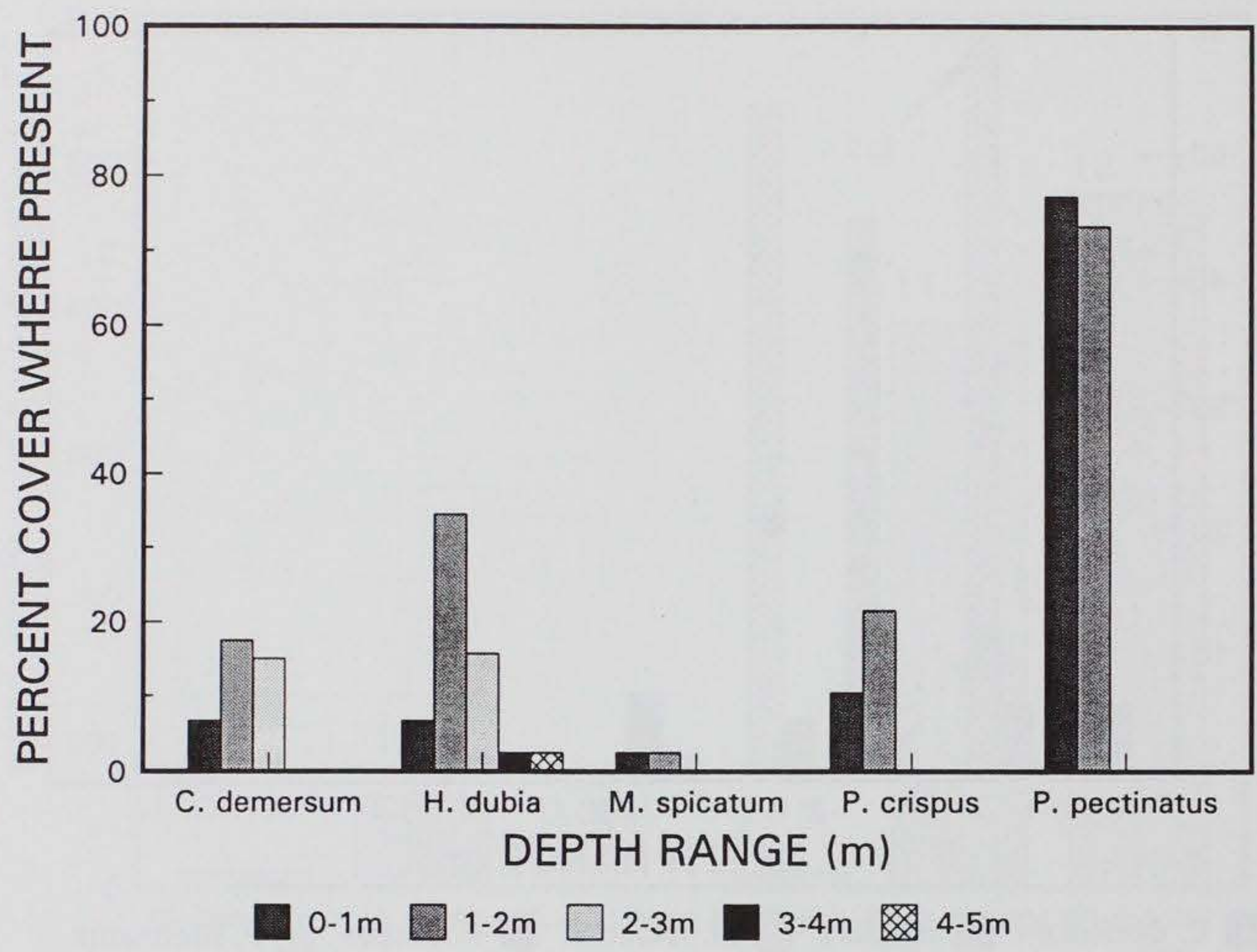

Figure 6. Depth distribution of aquatic plants in Onondaga Lake by average percent cover in quadrats where plants are found: PP, Potamogeton pectinatus; PC, P. crispus; MS, Myriophyllum spicatum; HD, Heteranthera dubia; CD, Ceratophyllum demersum

zone to wetlands. The lack of these species may be related to water level changes or water chemistry, as well as shoreline changes associated with urbanization and wave scouring of unstable sediments.

Individual sites (transects) exhibited very limited species diversity, with an average of slightly more than 1 species per transect (mean $=1.3$ ). The number of species at each site ranged from 0 to 3 (Figure 9). Potamogeton pectinatus was the most common, occurring at 27 of the 40 transects $(68 \%)$. The remainder of species were found in the following order: Heteranthera dubia (10 of the 40 transects, 25\%), Ceratophyllum demersum (7, 18\%), Potamogeton crispus $(5,13 \%)$, and Myriophyllum spicatum (2, 5\%).

Species richness of all groups of aquatic plants is very low for New York lakes, as indicated in Table 2. Typically, a New York lake will have an average of 18 species of aquatic plants: 14 submersed, 2 floating-leaved, and 2 emergent species. Even the historical estimate of 15 species of vascular plants from the lake's edge and deeper is low for a eutrophic lake of this type (Table 2). Of the 15 species listed, 8 are submersed species. For 31 eutrophic lakes from around the world, the average number of submersed 


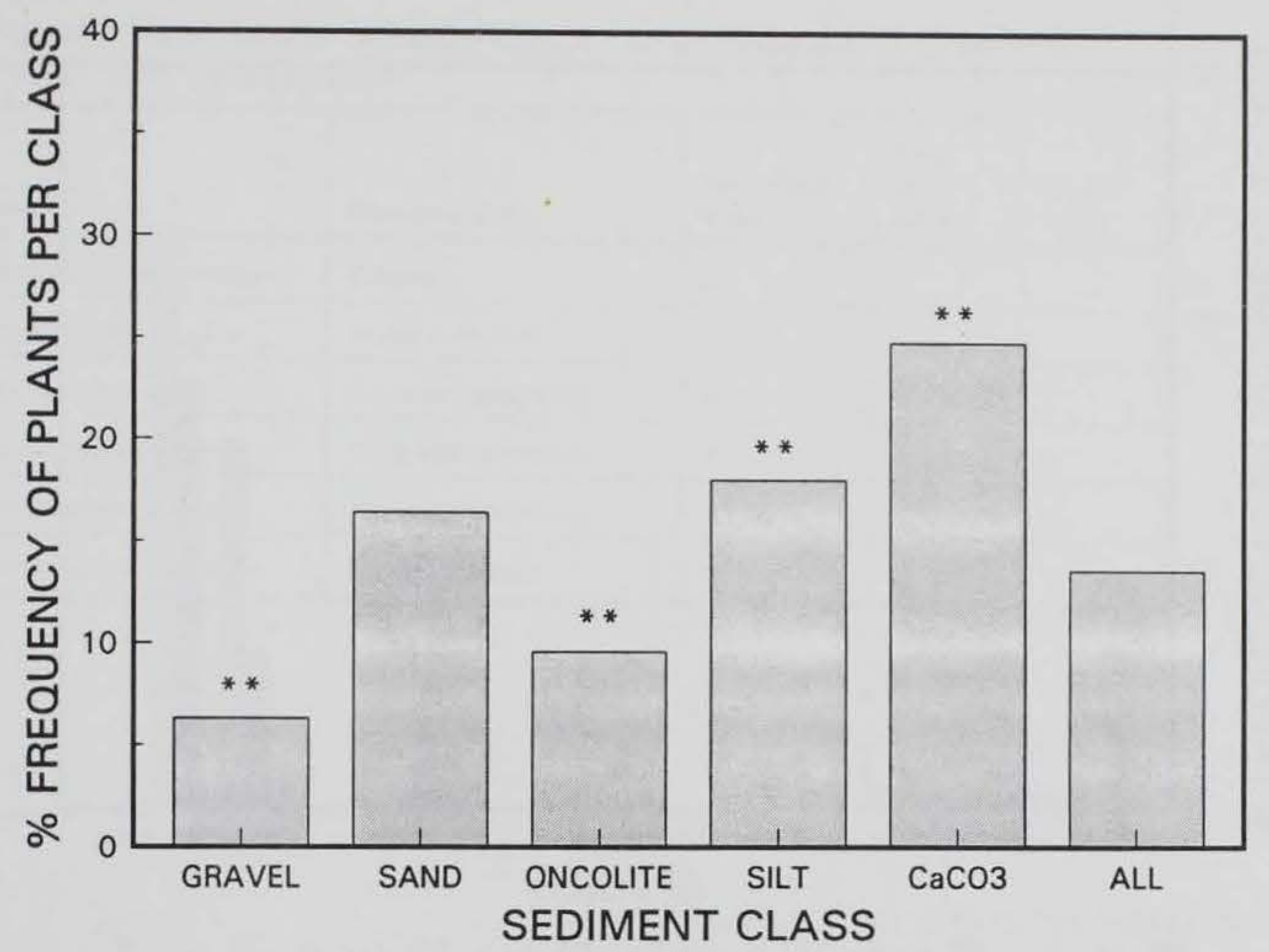

Figure 7. Percent of Onondaga Lake aquatic plants relative to sediment type. Asterisks indicate significant difference from the distribution of all sediment types by a Chisquare test on a two-by-two table

species was 4.4 , and an average of 6.6 for all 439 lakes examined (Taggett et al. 1990). With no floating-leaved or emergent species and only 5 submersed species, Onondaga Lake observations from 1991 are below the New York average but similar to the world average. Many factors can contribute to this low species diversity, including degree of eutrophication, salinity, size of lake, and degree of urbanization. Oligo- and mesotrophic lakes tend to have the highest species diversity of submersed plants, with eutrophic lakes of substantially lower diversity (Taggett et al. 1990). Saline lakes tend to have even lower diversity of submersed species, since only a few plants tolerate highly saline conditions. The probable factors in the decline of species richness for Onondaga Lake may have been the increased salinity of the lake, and the increased cultural eutrophication resulting in low transparency. As salinity or chemical content of the water decreases, species diversity should increase; but abundance and diversity will continue to be limited by sediment quality. Also, improvements in other water quality parameters, such as increased transparency and decreased algal growth, should result in higher species diversity as well.

The abundance of the five submersed species around the lake is evidenced by the number of transects at which each was observed (Table 8, Figure 9).

Of the five species observed, Potamogeton pectinatus was common and locally 


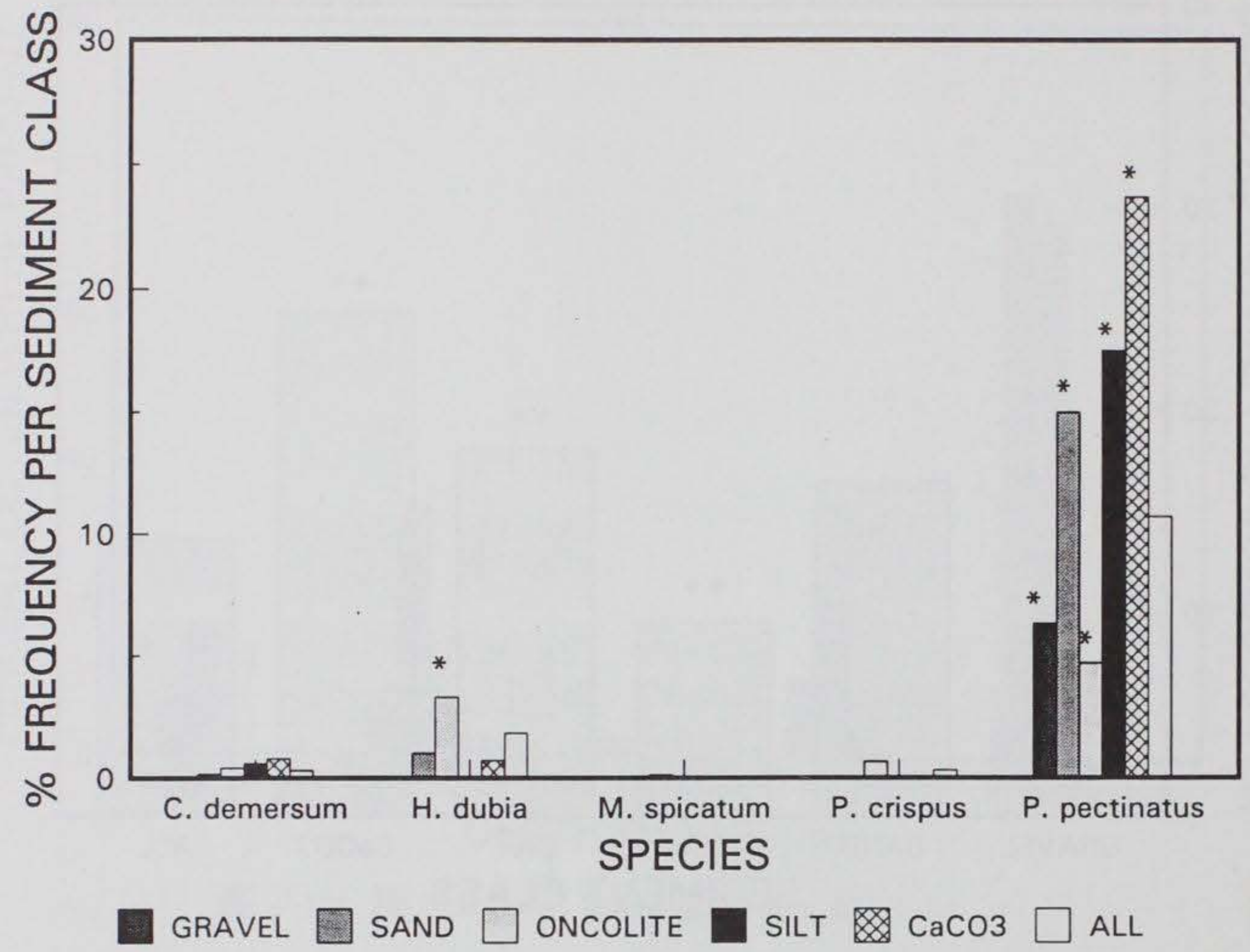

Figure 8. Frequency distribution of aquatic plants in Onondaga Lake relative to sediment type: PP, Potamogeton pectinatus; PC, P. crispus; MS, Myriophyllum spicatum; HD, Heteranthera dubia; CD, Ceratophyllum demersum. Asterisk indicates a significant difference from the occurrence of this species on all sediments by a Chisquare test on a two-by-two table

abundant, Heteranthera dubia was present at many locations, and the remaining three species were infrequently observed, or rare, and never common or abundant at any site.

Ceratophyllum demersum (Coontail) was observed at only 7 transects, or $18 \%$ of sites. Coontail is a nonrooted submersed aquatic plant that was typically found intermingled with other dense growths of aquatics, and was not found in great abundance. Most occurrences were in less than $2 \mathrm{~m}$ of water, among growths of Potamogeton pectinatus.

Heteranthera dubia (Water stargrass) was observed at $25 \%$ of the sites. It had the deepest range, occurring out to 4-m water depth in the northeastern part of the lake. Generally, it was found adjacent to stands of $P$. pectinatus in 1- to 3-m depth.

Myriophyllum spicatum (Eurasian watermilfoil) was observed as small colonies at only two locations, in 0 - to $2-\mathrm{m}$ water depth. Eurasian watermilfoil is a nonnative species that creates nuisance problems in many lakes 


\begin{tabular}{|c|c|c|c|c|}
\hline \multicolumn{5}{|c|}{$\begin{array}{l}\text { Table } 7 \\
\text { Aquatic Macrophyte Species List for Onondaga Lake, Nine Mile } \\
\text { Creek, and Otisco Lake }\end{array}$} \\
\hline Specles & Common Name & $\begin{array}{l}\text { Onondaga } \\
\text { Lake }\end{array}$ & $\begin{array}{l}\text { Nine } \\
\text { Mile } \\
\text { Creek }\end{array}$ & $\begin{array}{l}\text { Otisco } \\
\text { Lake }\end{array}$ \\
\hline Ceratophyllum demersum & Coontail & $x$ & & \\
\hline Heteranthera dubia & Water stargrass & $x$ & & \\
\hline Myriophyllum spicatum & Eurasian watermilfoil & $x$ & $x$ & $x$ \\
\hline Potamogeton crispus & Curly-leaf pondweed & $x$ & $x$ & $x$ \\
\hline Potamogeton nodosus & American pondweed & & $x$ & $\mathrm{x}$ \\
\hline Potamogeton pectinatus & Sago pondweed & $x$ & & \\
\hline
\end{tabular}

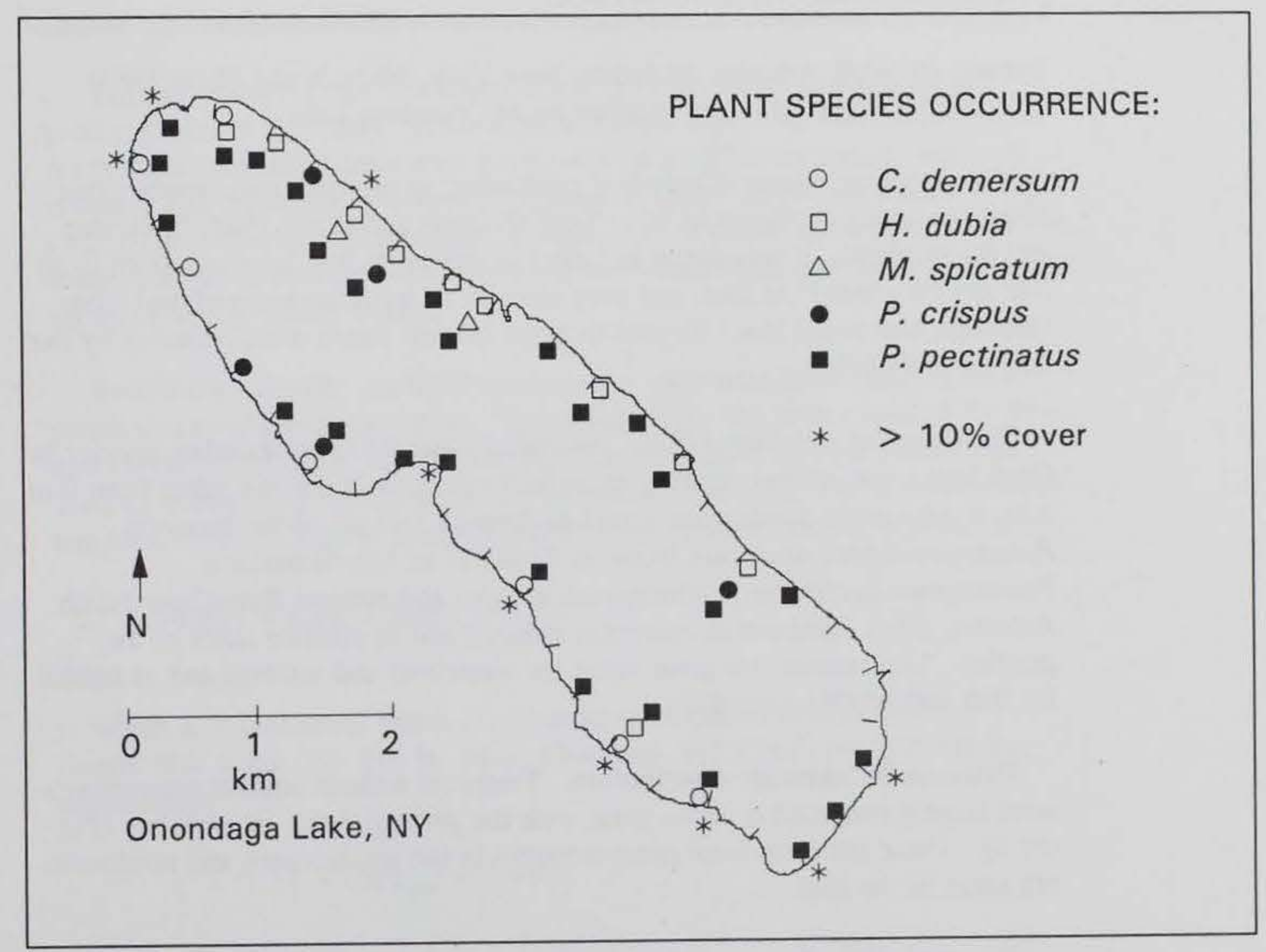

Figure 9. Aquatic plant species distribution in Onondaga Lake 


\begin{tabular}{|c|c|c|c|c|c|c|}
\hline \multicolumn{7}{|c|}{$\begin{array}{l}\text { Table } 8 \\
\text { Depth Distribution and Abundance of Macrophyte Species in } \\
\text { Onondaga Lake at the } 40 \text { Survey Transects }{ }^{1}\end{array}$} \\
\hline \multirow[b]{2}{*}{ Species } & \multicolumn{6}{|c|}{ Depth Range (m) } \\
\hline & $0<1$ & $1<2$ & $2<3$ & $3<4$ & $4<5$ & Total \\
\hline Ceratophyllum demersum & 5 & 3 & 1 & 0 & 0 & 7 \\
\hline Heteranthera dubia & 3 & 8 & 4 & 1 & 1 & 10 \\
\hline Myriophyllum spicatum & 1 & 1 & 0 & 0 & 0 & 2 \\
\hline Potamogeton crispus & 3 & 3 & 0 & 0 & 0 & 5 \\
\hline Potamogeton pectinatus & 22 & 12 & 0 & 0 & 0 & 27 \\
\hline
\end{tabular}

throughout North America, including New York (Nichols and Shaw 1986). This species bears continued monitoring in Onondaga Lake.

Potamogeton crispus (Curly-leaf pondweed) is another exotic species that creates nuisance problems in New York (Nichols and Shaw 1986; Tobiessen and Snow 1984). It was found in larger quantities at five locations from 0 - to 2-m depths around the lake, and may actually be more widespread and more abundant than noted since its growth cycle is such that it often senesces by late June or early July.

Potamogeton pectinatus (Sago pondweed) was the most abundant species in Onondaga Lake, often occurring as large dense beds in shallow areas from 0 to $2 \mathrm{~m}$, though some plants were found as deep as $3 \mathrm{~m}$ off of the transects.

Potamogeton pectinatus was found at $27(68 \%)$ of the 40 transects.

Potamogeton pectinatus is widespread in lakes and streams throughout North America, often dominant in eutrophic streams and in alkaline lakes of the prairies. This species has great value for waterfowl and wildlife and as habitat for fish and benthic organisms.

Patterns in lakewide distribution. Transects without aquatic macrophytes were largely restricted to those areas with the greatest fetch, or exposure (Figure 9). These transects were predominantly in the southeastern and northwestern areas of the lake.

Ceratophyllum demersum was found predominantly along the western shore, with $H$. dubia found predominantly on the eastern shore. Myriophyllum spicatum was found at two nearly adjacent transects northwest of the marina on the northeastern shore. Potamogeton crispus was distributed sparsely around the entire lake. 
In most locations, existing $P$. pectinatus populations were very small. Two locations, northwest of the outlet (T19) and southwest of Onondaga Creek (T39), had large beds of Potamogeton pectinatus (Figures 1, 9). Only once did a site have macrophytes without $P$. pectinatus being present. At all other transects, beds of $P$. pectinatus were small, which seems to indicate that their establishment has been recent. The total areal coverage of $P$. pectinatus was much less than typical lakes, or than depth conditions should allow. The populations at individual sites are generally small, with a large amount of space yet available for expansion. The scarcity of other species would also support the idea that their establishment has been recent, as well. Potamogeton pectinatus, being more tolerant of high salinity than most species, probably recolonized the lake first or has existed in the most favorable locations, such as the two listed above. Reestablishment at other locations has been recent. New species are probably slow to recolonize due to the persistent high salinities and the low transparency and small window of opportunity of higher transparency conditions.

The factors that appear to limit plant distribution and abundance are transparency, salinity, water level, wave action effects on unstable sediments, and the ability of new species to colonize this newly available littoral zone. These factors are discussed below.

Transparency. Light is a major limiting factor for submersed aquatic plants (Barko et al. 1986). These limitations are expressed both in the maximum depth to which plants may grow, as well as different species that may colonize and thrive under differing regimes of light. Light penetration is typically measured with a Secchi disk, though more accurate measurements can be made with an underwater irradiometer (from which light attenuation coefficient estimates are generally made).

Secchi disk depth. As light transparency increases, submersed aquatic plants can colonize deeper areas. This relationship has been explored by several investigators using Secchi disk depth as a measure of light penetration. Two such empirical relationships are shown in Figure 10. For over 100 north temperate lakes, Canfield et al. (1985) developed the following expression:

$$
\log \left(z_{c}\right)=0.61 * \log z_{S D}+0.26
$$

in which $z_{c}=$ maximum depth of macrophyte colonization $(\mathrm{m})$, and $z_{S D}=$ Secchi disk depth (m). For 90 lakes, Chambers and Kalff (1985) found the relationship:

$$
z_{c}=\left(1.33 * \log \left(z_{S D}\right)+1.40\right)^{2}
$$

This relationship was found to be further moderated by other optical properties of lakes, such as color (Chambers and Prepas 1988). 


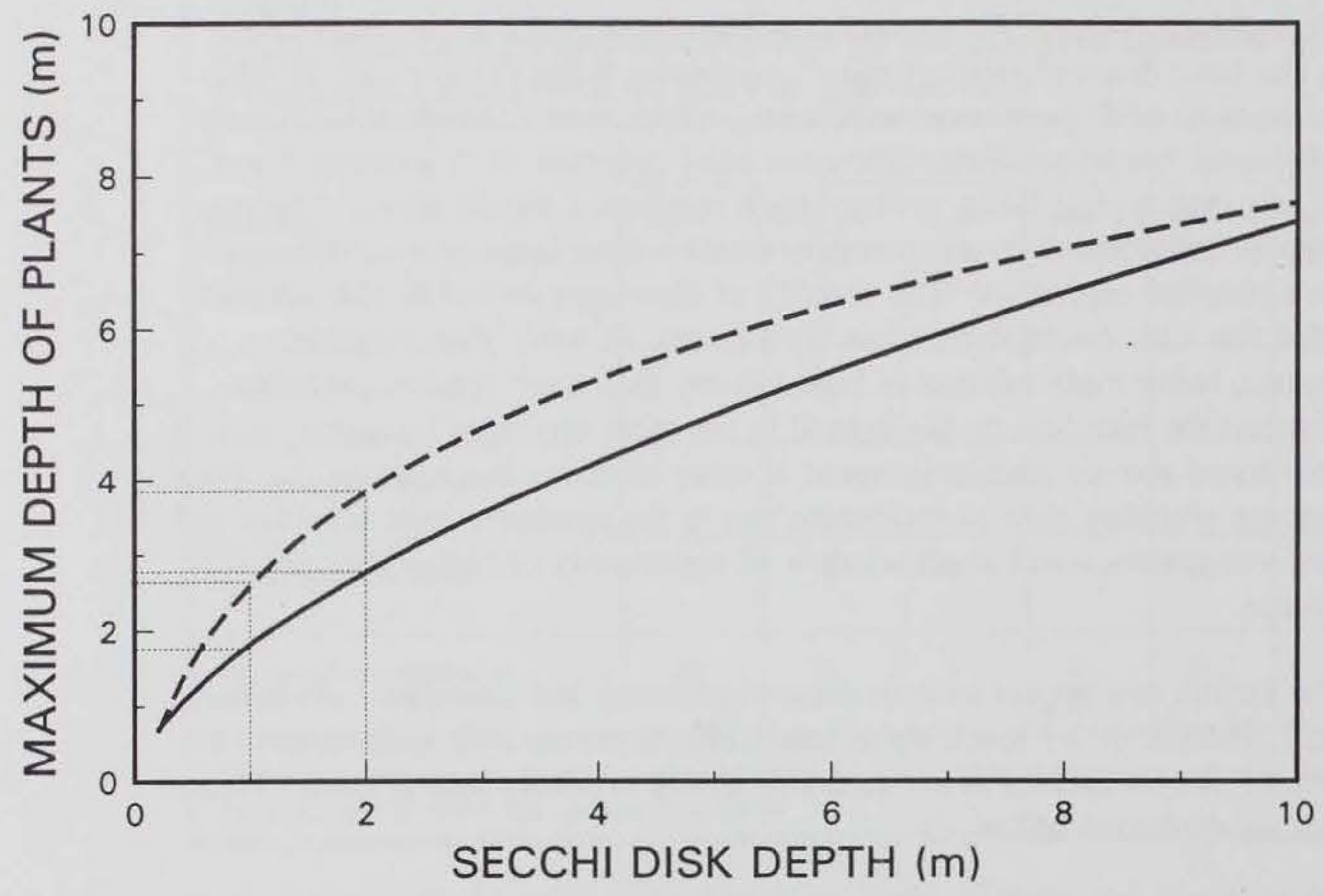

Canfield et al. 1985 Chambers \& Kalff 1985

Figure 10. Depth of colonization of aquatic macrophytes according to empirical relationships by Canfield et al. (1985) and Chambers and Kalff (1985)

Based on the summer average value of $z_{S D}$ (in $\mathrm{m}$ ) for the period 1978 to 1990 (Effler 1992), these two models predict a maximum depth of plant colonization in Onondaga Lake of 1.8 and $2.6 \mathrm{~m}$, respectively. The average Secchi disk depth in Onondaga Lake has increased in recent years (1987 to 1990) to about $2.0 \mathrm{~m}$ (Effler 1992), which would correspond to a maximum depth of colonization of 2.8 to 3.8 . This depth interval essentially corresponds to the maximum depth of colonization of 3 to $4 \mathrm{~m}$ observed in 1991. Further increases in Secchi disk depth should be expected to result not only in a greater maximum depth of colonization but also in increased species diversity as a wider range of light and other habitat factors (discussed subsequently) create more habitat for plant growth. Other aspects of increased maximum depth of colonization include the importance of water level fluctuations and disturbance, which will be discussed in greater detail later.

Attenuation coefficient $\left(\mathbf{K}_{\mathbf{d}}\right)$. Another approach to examining the relationship between light transparency and the depth of plant colonization utilizes the attenuation coefficient $\left(\mathrm{K}_{\mathrm{d}}\right)$ rather than Secchi disk depth. Using data from 15 New Zealand lakes of a wide range of transparencies, Vant et al. (1986) derived the following empirical relationship: 


$$
z_{c}=\frac{4.34}{K_{d}}
$$

The summer average $K_{d}$ for Onondaga Lake for 10 years in the interval 1978 to 1990 is indicated in Figure 11, with the bars indicating minimum and maximum values (data from Effler 1992). Using these values in equation 3, the potential for plant colonization is indicated in Figure 11. Although the calculated mean maximum depth has changed little (approximately $2.5 \mathrm{~m}$ ), the timing of the clearing period during the summer in recent years, as exemplified for 1988 in Figure 11, indicates that there may be a window of opportunity for some species to grow deeper. Beginning in 1987, a window of clearing transparency appeared early in the growing season, which some macrophyte species might be able to exploit. These species would be early season plants, or species that are fully grown and senesce by midsummer. Examples of species that might do well under these conditions, and are presently found in the lake, include Potamogeton crispus, $P$. pectinatus, and possibly Myriophyllum spicatum. Conversely, some species with a perennial growth form or ones that dominate later in the growing season would not have an advantage, such as Elodea canadensis or Potamogeton robbinsii. Other species, such as Najas spp., might not be able to complete their life cycle before reduced transparency would cause parent plant mortality. The first few years, this "window" was approximately 4 weeks long, but the "window" in 1990 was almost 6 weeks long. It may take several more years to understand this clearing event, and to see if it is changing. The potential impact of the timing and duration of clearing on macrophyte growth and colonization warrants further investigation. Undoubtedly, this event is significant to aquatic plant growth and can only assist aquatic plants in growth and revegetation.

Water chemistry. Onondaga Lake is more similar in water chemistry to many of the inland saline prairie lakes than lakes found in upstate New York. Not only does the water chemistry itself undoubtedly limit a large number of aquatic macrophytes from inhabiting the lake, but many of the species adapted to saline freshwater environments have no avenue of access to this lake. Although salinity (also $\mathrm{Cl}^{-}$and conductivity) has decreased from earlier levels (Effler 1992), past high concentrations of solutes may have been sufficient alone to prohibit many common emergent and floating-leaved species, due to increased stress from evapotranspiration. Although many submersed macrophytes are not tolerant of high salinities, some species show a surprising degree of tolerance (Table 9). Many of these species may in general be tolerant of high salinity, while for others selected populations may develop a tolerance to saline conditions. Several submersed species are notable for being tolerant to high solute concentrations, such as $P$. pectinatus. The dominance of $P$. pectinatus in Onondaga Lake is probably in part due to its tolerance to high solute concentrations. Its current dominance may continue as it has preempted many habitats from other species, although as solute concentrations continue to decrease, other species may increase in abundance. Decreased concentrations of solutes may also encourage the growth of emergent and floating-leaved species. 

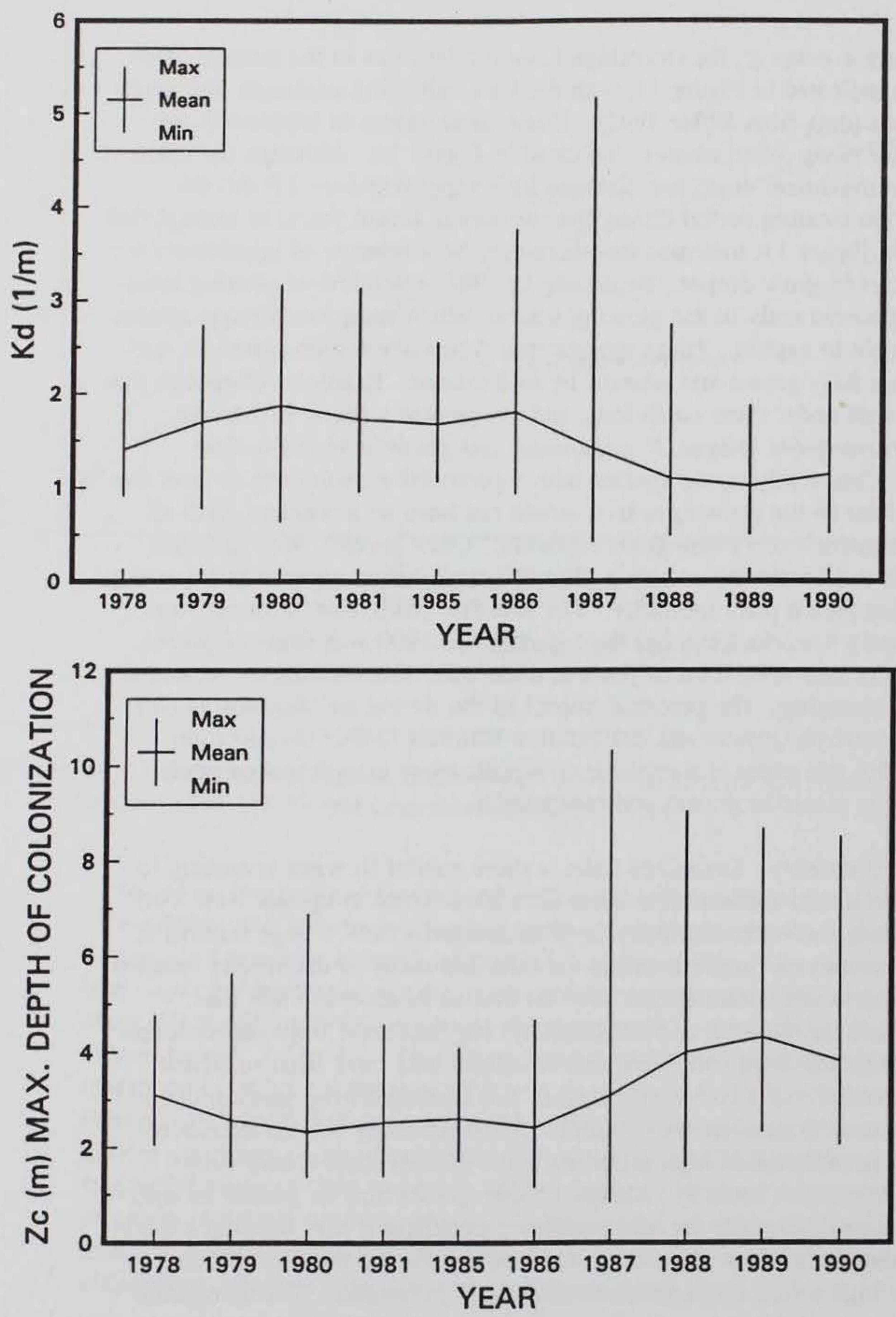

Figure 11. $K_{d}$ (from Effler 1992) and maximum depth of colonization calculated (from Vant et al. 1986) from attenuation coefficient 


\section{Table 9}

Tolerance Range of Some Tolerant Aquatic Macrophytes for Salinity, $\mathrm{Cl}^{-1}$, and Conductivity Levels in Fresh Water

\begin{tabular}{|c|c|c|c|c|}
\hline Species & $\begin{array}{l}\text { Salinity } \\
\left(\mathrm{g} \mathrm{r}^{-1}\right)\end{array}$ & $\begin{array}{l}\text { Conduct. } \\
\left(\mathrm{mS} \mathrm{cm}^{-1}\right)\end{array}$ & $\begin{array}{l}\mathrm{Cr} \\
\left(\mathrm{mg} \mathrm{r}^{-1}\right)\end{array}$ & Reference \\
\hline Brasenia schreberi & & $<238$ & $<255$ & Kadono (1982) \\
\hline Ceratophyllum demersum & & $<16200$ & $<5790$ & Kadono (1982) \\
\hline Hydrilla verticillata & $<10$ & & & Haller et al. (1974) \\
\hline H. verticillata & & $<10900$ & $<3910$ & Kadono (1982) \\
\hline Lemna minor & \pm 16.65 & & & Haller et al. (1974) \\
\hline Lemna minor & $<10$ & & & Hammer \& Heseltine (1988) \\
\hline Myriophyllum spicatum & $<16.65$ & & & Haller et al. (1974) \\
\hline Myriophyllum spicatum & $<10$ & & & Hammer \& Heseltine (1988) \\
\hline M. spicatum & & $<15100$ & $<4830$ & Kadono (1982) \\
\hline M. verticillatum & & $<183$ & $<83.3$ & Kadono (1982) \\
\hline Najas guadalupensis & $<13.32$ & & & Haller et al. (1974) \\
\hline N. marina & & $<10900$ & $<3910$ & Kadono (1982) \\
\hline Phragmites australis & $10-20$ & & & Hammer \& Heseltine (1988) \\
\hline Potamogeton pectinatus & $<58$ & & & Hammer \& Heseltine (1988) \\
\hline P. richardsonii & $<10$ & & & Hammer \& Heseltine (1988) \\
\hline Ruppia maritima & $<70$ & & & Hammer \& Heseltine (1988) \\
\hline R. occidentalis & $<58$ & & & Hammer \& Heseltine (1988) \\
\hline Trapa natans & & $<219$ & $<255$ & Kadono (1982) \\
\hline Typha latifolia & $<10$ & & & Hammer \& Heseltine (1988) \\
\hline Utricularia vulgaris & $<10$ & & & Hammer \& Heseltine (1988) \\
\hline Vallisneria americana & $<13.32$ & & & Haller et al. (1974) \\
\hline V. asiatica & & $<9800$ & $<330$ & Kadono (1982) \\
\hline
\end{tabular}

The tolerance data presented in Table 9 may be somewhat misleading, in that these data are either observed ranges of conditions at which the species is found, or may result from experimental studies in which competition and other factors are eliminated. For Onondaga Lake, there is no avenue (other than human intervention) for most tolerant species or ecotypes to reach this lake, so the native colonizing pool of species are not typically tolerant of saline conditions (save $P$. pectinatus). Also, salinities of even one-tenth to one-hundredth the range observed in Table 9 may be sufficient to reduce the growth and production of aquatic plants. In these instances, plants may survive under experimental conditions, but would not be able to compete with other species or survive the disturbances common in natural settings. The addition of salinity stress may be sufficient to prevent submersed species from surviving in 
Onondaga Lake against algal competition for light and other environmental stresses.

Another aspect of increased concentrations of calcium chloride in Onondaga Lake waters is the production of calcium carbonate precipitates to the lake bottom and onto plant surfaces. Under high concentrations of dissolved calcium, precipitation of calcium carbonate can occur onto plant surfaces resulting in "marl" formations (Wetzel 1960). This process can be passive, with the plant being a catenation point for precipitation, or active through bicarbonate use in photosynthesis (Smart and Barko 1988; Smart 1990; Wetzel 1983). If the rate of marl formation exceeds the rate of plant growth, the plant could become buried in marl. In fact, this mode of mortality has been a point of conjecture for the disappearance of Chara from Onondaga Lake (Dean and Eggleston 1984). In addition, this mechanism may also be effective against other species, such as $P$. pectinatus and $M$. spicatum.

The levels of calcium in the water column were sufficient in the past to produce large amounts of marl, adequate to bury plants by calcium carbonate encrustation (Effler and Driscoll 1985). As calcium concentrations have dropped, the rate of deposition has also decreased (see Effler 1992). This change in deposition rate is another factor which may be operating to allow expansion of aquatic plant populations within the lake.

Water level. Variations between years and within a given year appear to be less than $1 \mathrm{~m}$ (Effler 1992). Even these minor variations in water level may have a significant effect on the littoral zone vegetation of the lake, since light penetration restricts the depth of macrophyte growth to such shallow depths (Figure 11). Combined with the impacts of water level on the upper limit of plant growth are the added impacts of wave action and ice scour. Water level, wind-generated waves, ice scour, and low transparency may have acted in concert to greatly restrict plant distribution and abundance in the past. However, recent improvements in solute concentrations and transparency may be allowing macrophyte recolonization and expansion.

Watershed effects and invasive plants. For the most part, Onondaga Lake is an improving, yet largely open, habitat for aquatic plants. Water composition, mostly as salinity, is improving to levels more generally tolerated by aquatic plants. Light penetration is improving to levels acceptable to a large number of submersed plants. The existence of few large beds and limited distributions of most plants suggest that colonization is largely recent and, at this point, relatively slow. The composition of the future macrophyte community is largely dependent on the plant propagules that can make it to the lake environment. It is commonly presumed, without much supporting data, that waterfowl carrying seeds in their digestive tracts is the single most important mode of transport for aquatic plants propagules, particularly seeds.

Although this is a viable method of distribution, the two most important mechanisms for plant dispersal are water movement and man (not necessarily in that order). Human introduction of plants to new environments may be either intentional, such as planting, or inadvertent. The most common mode of 
aquatic plant dispersal by man is the transport of plant fragments or propagules on boats and boat trailers (Johnstone et al. 1985).

Downstream water movement is the most powerful and consistent carrier of plant propagules. Therefore, we can expect the upstream water bodies from Onondaga Lake to have a heavy impact on the composition of plants in it. In Table 7, some plant species observed in Nine Mile Creek and Otisco Lake are recorded (this is by no means an exhaustive list). Two of those species, $M$. spicatum and $P$. crispus, are already found in small numbers in Onondaga Lake. As salinity decreases, the abundance of these two species could possibly increase - eventually leading to a more typical composition for a eutrophic New York lake. Since these species are found in abundance upstream of Onondaga Lake, it is unlikely that their continual introduction can be prevented. The other species sighted in Nine Mile Creek, $P$. nodosus, probably as yet cannot tolerate water conditions in the lake. However, it is very likely that it has been introduced repeatedly to the lake.

\section{Greenhouse Studies}

\section{Water quality of greenhouse tanks}

As indicated in Table 10, the water quality of the tanks varied little during the two test periods. In both trials, nitrate and ammonium concentrations began at relatively high levels and were depleted, mostly by the growth of algae in the tanks and on the tank filters. This algal growth did not interfere with the tests, since algal growth was actively removed through the use of diatomaceous earth filters.

\section{Sediment survey growth bioassay greenhouse experiment}

Sediment types. Growth of Potamogeton pectinatus was significantly higher on the Lewisville reference sediment than on all of the Onondaga Lake sediments (Figure 12). Growth was no different on the four basic sediment types. This may be due to the fact that, although sediments appeared different, analysis of these sediments indicated that all were high in $\mathrm{CaCO}_{3}$, or of oncolitic origin. Sediment visual classes alone did not differentiate significant growth potentials of sediments. All Onondaga Lake sediments produced less growth than the Lewisville reference sediment; thus, sediments either lack critical nutrients, or possibly have some stressful or slightly toxic substance. There were no statistically significant differences between visual classes, but sites T30 and T7 were exceptionally low in growth. Incidentally, neither site supported aquatic plants in Onondaga Lake.

Sediment mixtures. It was hypothesized beforehand that mixing sediments of other types with an oncolite sediment would increase the growth potential of oncolite sediments. Three of the four mixtures tried (oncolites with Lewisville, organic, and sand) did perform better than oncolites alone. All mixtures 


\begin{tabular}{|c|c|c|c|c|}
\hline \multicolumn{5}{|c|}{$\begin{array}{l}\text { Table } 10 \\
\text { Averages ( } \pm 1 \text { S.E.) of Water Chemistry Parameters in Greenhouse Tanks at } \\
\text { the Beginning and End of the Potamogeton pectinatus Trials (I) and Species } \\
\text { Survey Trials (II) })^{1}\end{array}$} \\
\hline Parameter & Begin Trial I & End Trial I & Begin Trial II & End Trial II \\
\hline Temperature $\left({ }^{\circ} \mathrm{C}\right)$ & $24.3 \pm 0.14$ & $24.1 \pm 0.42$ & $24.8 \pm 0.40$ & $25.0 \pm 0.20$ \\
\hline $\mathrm{pH}$ (units) & $8.1 \pm 0.04$ & $8.5 \pm 0.01$ & $7.8 \pm 0.09$ & $8.2 \pm 0.02$ \\
\hline $\begin{array}{l}\text { Dissolved Oxygen } \\
\text { (mg/l) }\end{array}$ & $8.5 \pm 0.07$ & $8.3 \pm 0.04$ & $8.5 \pm 0.09$ & $9.4 \pm 0.13$ \\
\hline $\begin{array}{l}\text { Conductivity } \\
(\mathrm{mS} / \mathrm{cm})\end{array}$ & $1.06 \pm 0.002$ & $1.16 \pm 0.008$ & $1.43 \pm 0.008$ & $1.13 \pm 0.022$ \\
\hline $\begin{array}{l}\text { Alkalinity } \\
\left(\mathrm{mg} \mathrm{CaCO}_{3} /\right)\end{array}$ & $339 \pm 3.4$ & $342 \pm 2.9$ & $322 \pm 3.7$ & $405 \pm 9.8$ \\
\hline $\mathrm{NO}_{3}-\mathrm{N}(\mathrm{mg} / \mathrm{l})$ & $0.05 \pm 0.009$ & $0.01 \pm 0.005$ & $0.10 \pm 0.028$ & $0.01 \pm 0.004$ \\
\hline $\mathrm{NH}_{3}-\mathrm{N}(\mathrm{mg} /)$ & $0.427 \pm 0.043$ & $0.049 \pm 0.015$ & $0.748 \pm 0.043$ & $0.030 \pm 0.002$ \\
\hline $\operatorname{SRP}(\mathrm{mg} / \mathrm{l})$ & $0.0065 \pm 0.0019$ & $0.0026 \pm 0.0005$ & $0.0033 \pm 0.0006$ & $0.0051 \pm 0.0012$ \\
\hline $\mathrm{Ca}^{+2}(\mathrm{mg} / \mathrm{l})$ & $9.17 \pm 1.24$ & $2.76 \pm 0.07$ & $9.20 \pm 1.05$ & $11.33 \pm 1.28$ \\
\hline $\mathrm{Mg}^{+2}(\mathrm{mg} /)$ & $0.34 \pm 0.014$ & $0.55 \pm 0.028$ & $0.42 \pm 0.027$ & $0.60 \pm 0.069$ \\
\hline $\mathrm{Na}^{+}(\mathrm{mg} / \mathrm{l})$ & $224 \pm 1.6$ & $272 \pm 12.6$ & $212 \pm 9.2$ & $217 \pm 6.6$ \\
\hline $\mathrm{K}^{+}(\mathrm{mg} / \mathrm{l})$ & $0.69 \pm 0.023$ & $0.44 \pm 0.100$ & $0.99 \pm 0.060$ & $0.89 \pm 0.266$ \\
\hline
\end{tabular}

produced growth similar to, or intermediate to, that obtained by their individual components, except for the oncolite-sand mixture (Figure 13). It does appear that mixing of sediments in situ, such as through the use of a rotovator, might improve plant growth.

Survey of lake sediments. Nine other sediments were selected, with three sediments each from areas of high, intermediate, and low observed plant abundance. Growth on these sediment types tended to reflect those perceived in situ abundance relationships (Figure 14). However, the exact mode of growth limitation is not evident. Sediment characteristics are not significantly different between these sites. An examination of plant tissue nutrients between high, medium, and low abundance sediment growth assays indicates that shoot nitrogen concentrations increase with decreasing growth, yet phosphorus content remains constant (Figure 15). Likewise, shoot nitrogen to phosphorus $(\mathrm{N}: \mathrm{P})$ ratios increase in the tissue of plants grown on low-abundance sediments. This might indicate that phosphorus, rather than nitrogen, is limiting in the low abundance sediments. The extremely high $\mathrm{CaCO}_{3}$ content of sediments may be acting to tie up sediment phosphorus in the low-abundance sediments.

The mean nitrogen content of bioassay plants ranged from 15 to $35 \mathrm{mg} / \mathrm{g}$ and that of phosphorus from 1.5 to $5 \mathrm{mg} / \mathrm{g}$ (Figure 16). Some of these values 


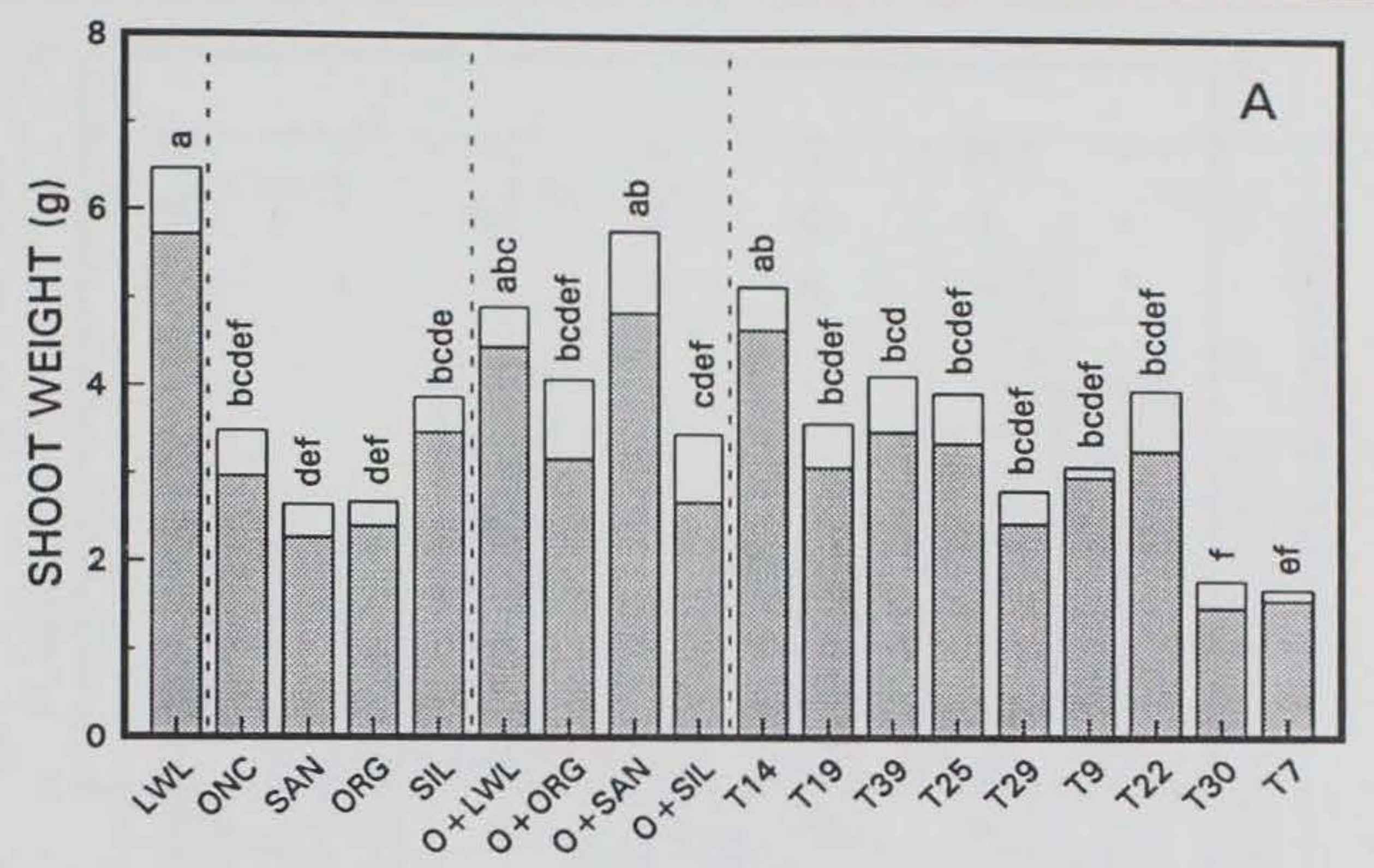

SEDIMENT SOURCE

$\square$ MEAN $\square+1$ SE

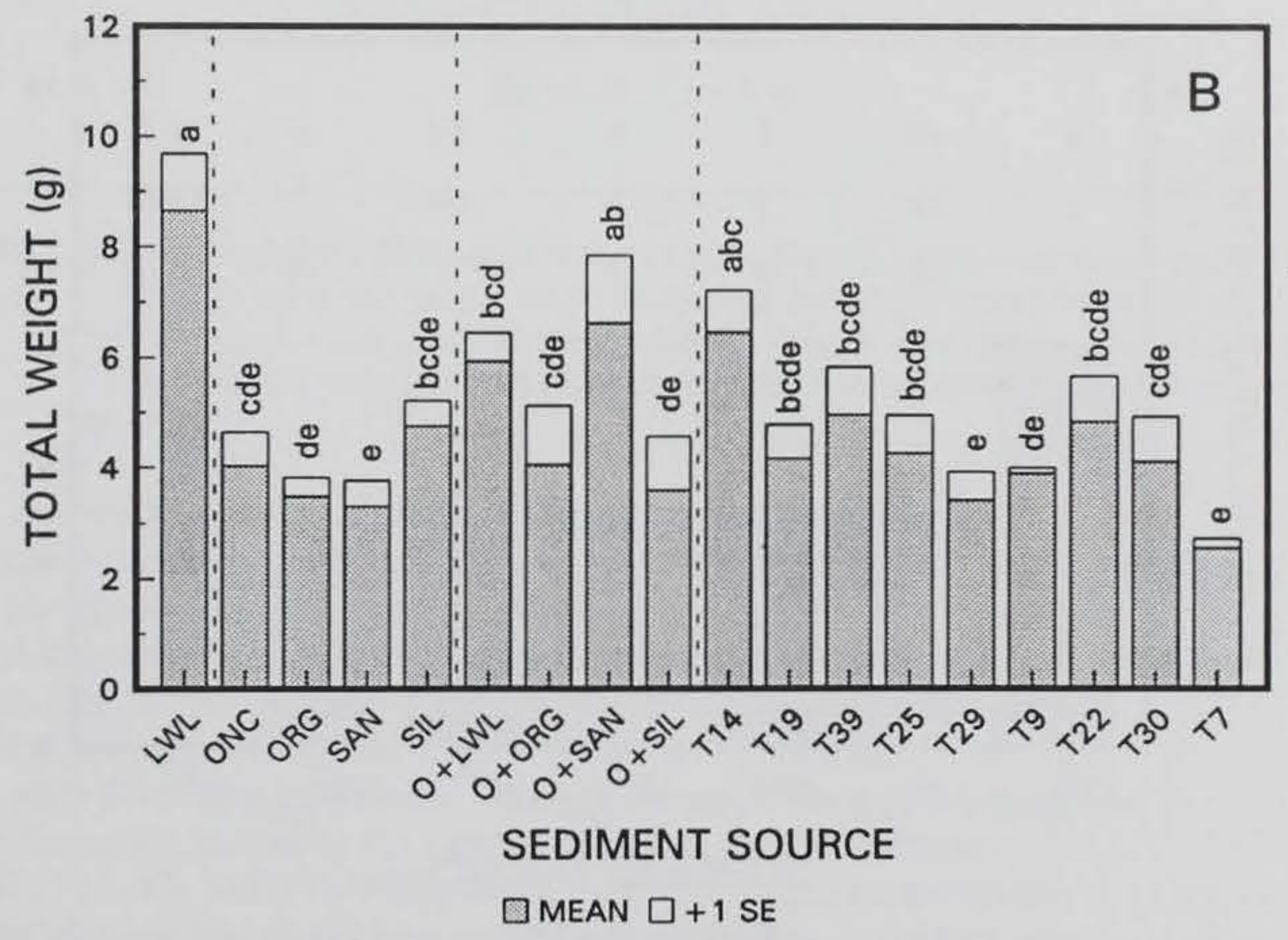

Figure 12. Growth of Potamogeton pectinatus in greenhouse studies using Onondaga Lake sediments and a Lewisville reference sediment, by sediment source: A. Shoot growth, B. Total weight. LWL, Lewisville; ONC, oncolite; SAN, sand; ORG, organic; SIL, silt; O+LWL, oncolite and Lewisville mixture; O+ORG, oncolite + organic; O+SAN, oncolite + sand; O+SIL, oncolite + silt; T\# = transect number for sediment origin. Means with different letters are significantly different using a least significant difference comparison on a one-way ANOVA 


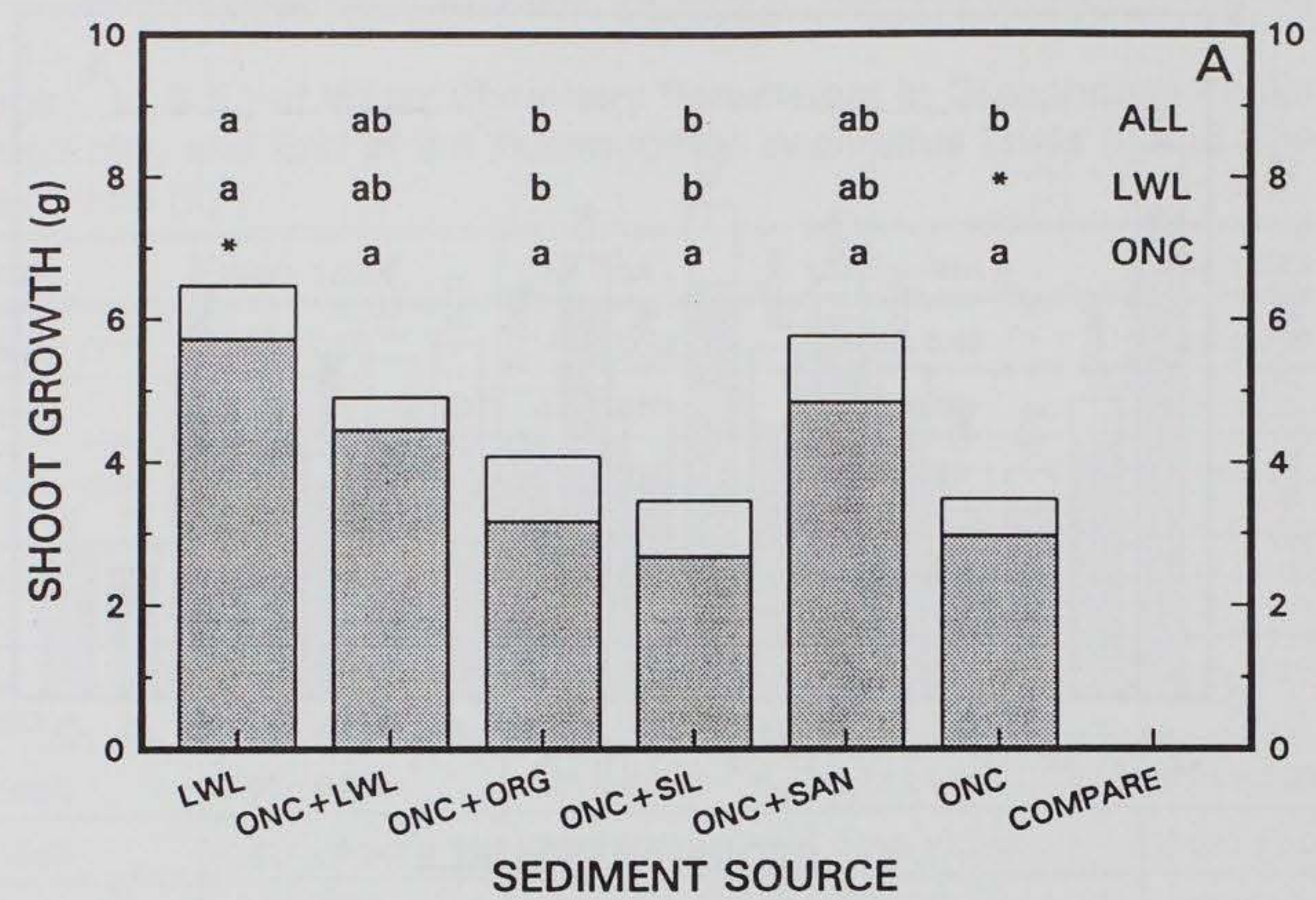

प MEAN $\square+1$ SE

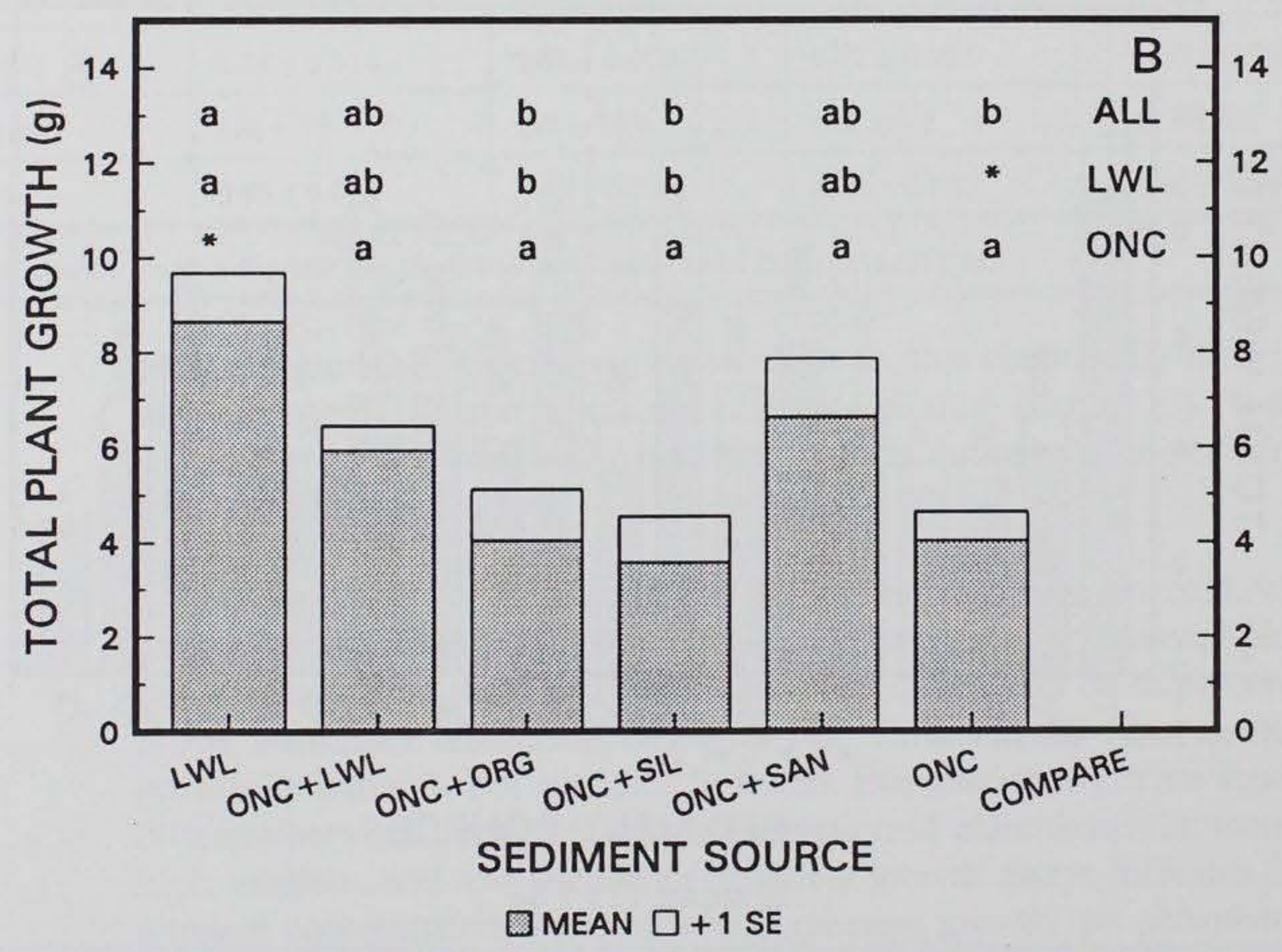

Figure 13. Growth of Potamogeton pectinatus in greenhouse studies using Onondaga Lake sediment mixtures and Lewisville reference, as analyzed by sediment classification; A. Shoot weight; B. Total plant weight. Comparison by ANOVA includes ALL (all sediments), LWL (ANOVA to Lewisville but not Oncolite), ONC (ANOVA with Oncolite but not Lewisville). Sediment source as above. Means with different letters are significantly different using a least significance difference comparison on a one-way ANOVA 


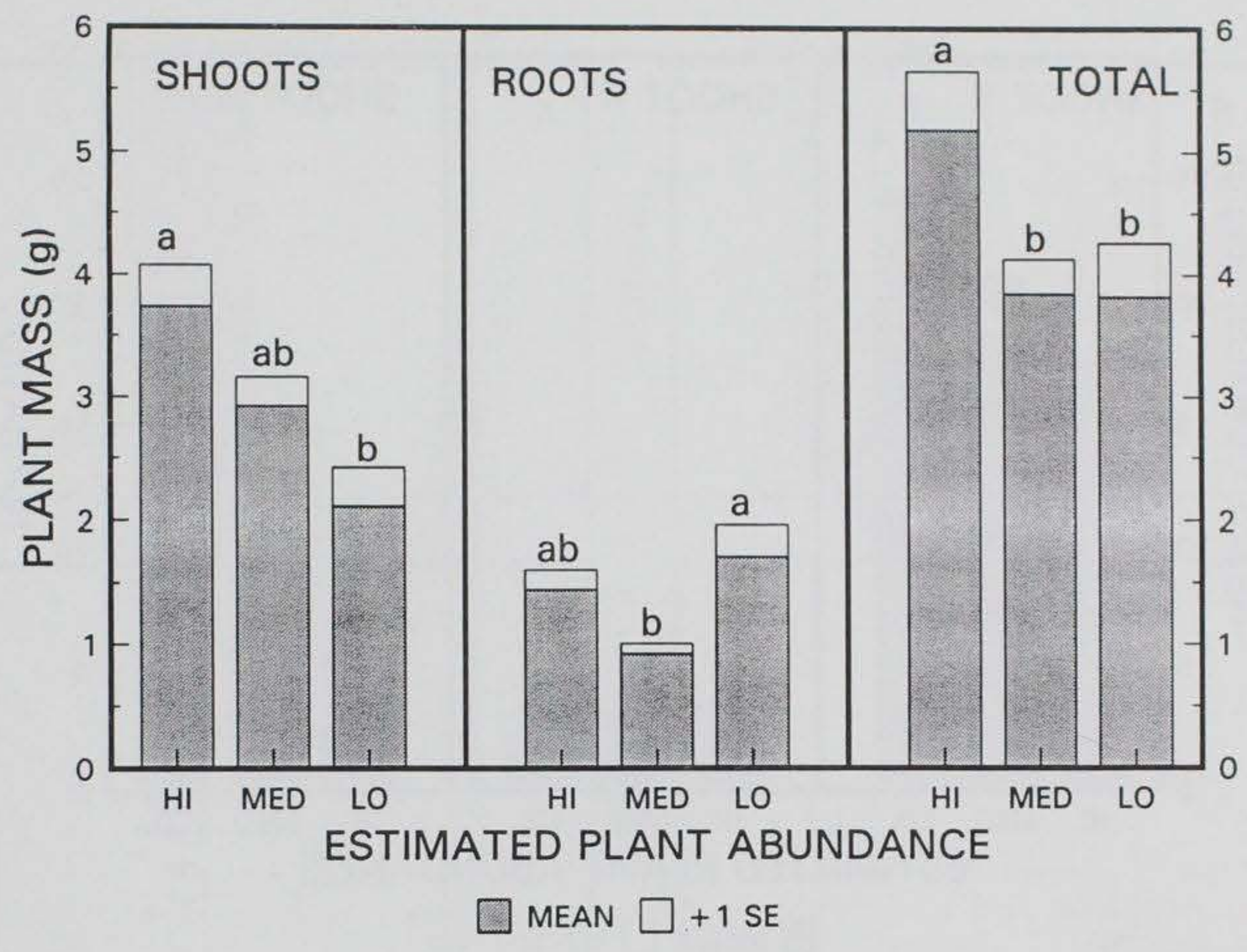

Figure 14. Growth of Potamogeton pectinatus in greenhouse studies using Onondaga Lake sediments, as analyzed by origin from sites with high, medium, or low plant abundance. Three sites per abundance class. Means with different letters are significantly different using a least significant difference comparison on a one-way ANOVA

are low and within a range of observed critical concentrations, suggesting nitrogen or phosphorus limitation of growth (Madsen 1991; 1992). In particular, the phosphorus contents of plants grown on the transect 30 sediments, a carbonate sediment type site, were below critical concentrations for phosphorus limitation (Figure 16B). Plants grown on this sediment showed a markedly higher N:P ratio (Figure 16C) and had a markedly higher root to shoot ratio (Figure 16D) than other treatments. Most of the sediments exhibited potential nitrogen limitation, including the Lewisville sediment. Five sediments (T3, $\mathrm{T} 22$, T39, T11+T3, and $\mathrm{T} 11+\mathrm{T} 20$ ), which exhibited tissue concentrations above the nitrogen and phosphorus critical ranges, may be limited by other nutrients or environmental factors.

\section{Species survey growth bloassay greenhouse experiment}

Eleven species were investigated on Onondaga Lake sediments: Elodea canadensis (EC), Myriophyllum spicatum (MS), Nymphaea odorata (NO), Potamogeton crispus (PC), P. nodosus (PN), P. pectinatus (PP), Sagittaria 


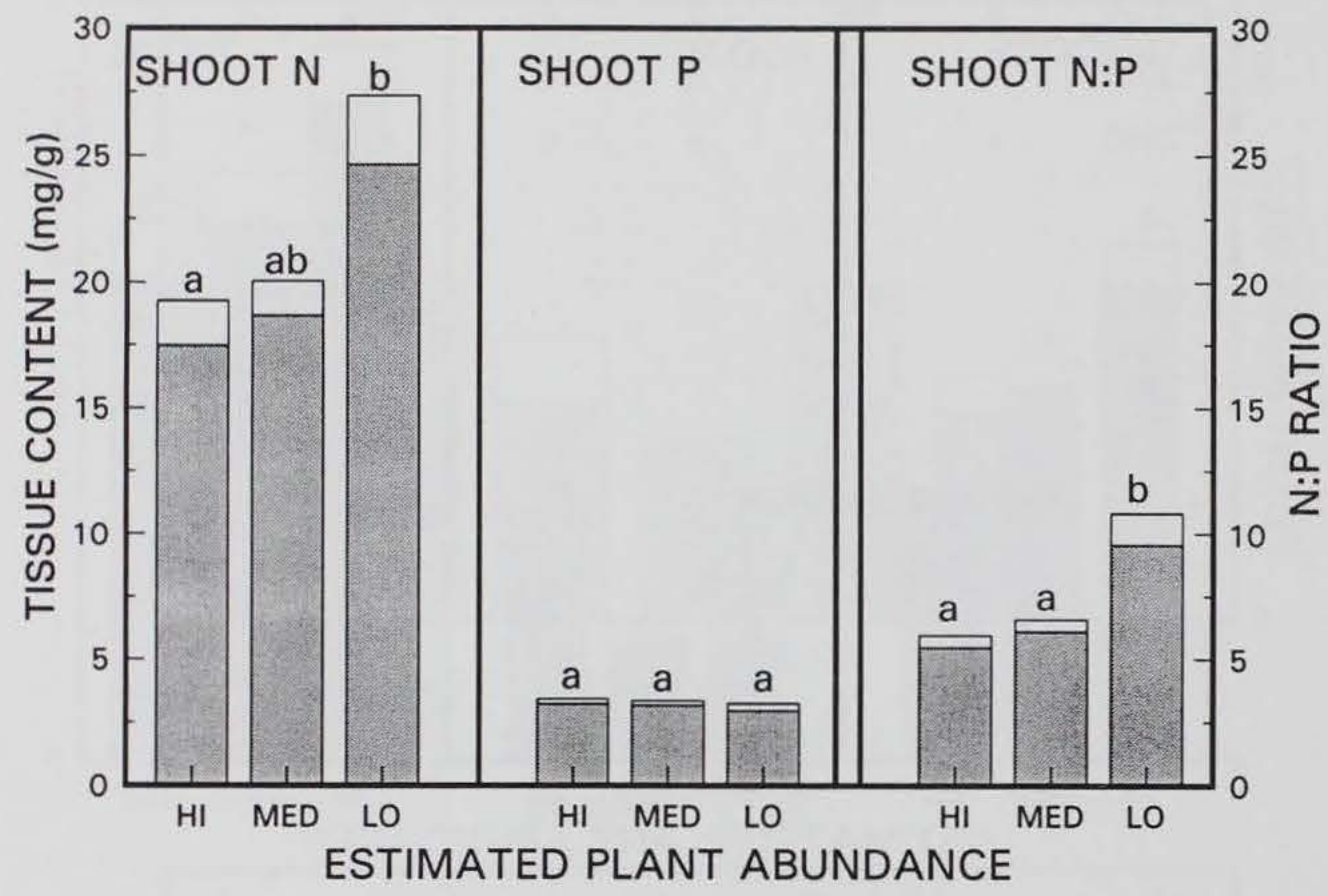

MEAN $\square+1$ SE

Figure 15. Shoot nitrogen, shoot phosphorus, and shoot N:P ratio for Potamogeton pectinatus in greenhouse studies using Onondaga Lake sediments from three plant abundance groups from which the sediments were collected. Three sites per plant abundance class. Means with different letters are significantly different using a least significant difference comparison on a one-way ANOVA

latifolia (SL), S. rigida (SR), Trapa natans (TN), Typha latifolia (TL), and Vallisneria americana (VA). All but two species were examined on Onondaga Lake oncolites (ONC), organic sediments from transect 20 (ORG), and a mixture of the two (ONC+ORG). The remaining two species (NO and SR) were only examined on oncolites. Three species (TN, NO and SR) were also cultured on a Lewisville sediment (LWL) (Table 11).

Growth patterns for species response to Onondaga Lake sediments included species growing best on oncolites, organic, or the mixture, or showing no preference for a given type of Onondaga Lake sediment (Figure 17). Species performing best on oncolites include $P$. pectinatus, $E$. canadensis, and $P$. crispus. These three species typically prefer coarser sediments. Vallisneria americana was the only species preferring either the organic sediment or mixture. The remaining five species tested on more than one Onondaga Lake sediment (PN, SL, MS, TL, and TN) exhibited no preference for sediment type. Of these, $P$. nodosus, $S$. latifolia, and $M$. spicatum grew well on the sediments. Typha latifolia had high shoot growth relative to other species, 

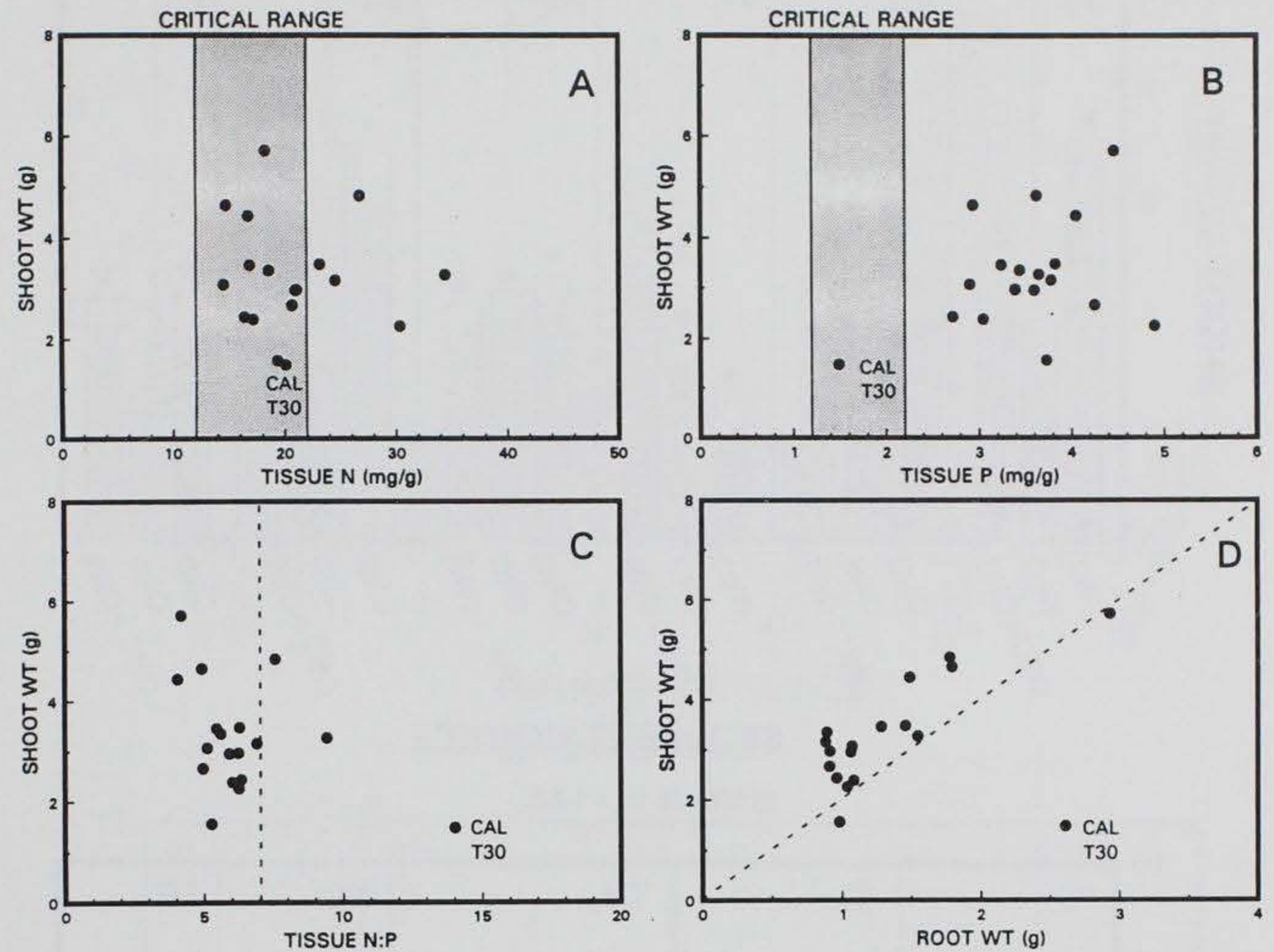

Figure 16. Growth of Potamogeton pectinatus in greenhouse studies using Onondaga Lake sediments and Lewisville reference: $A$, shoot tissue nitrogen versus shoot weight; $B$, shoot tissue phosphorus versus shoot weight; $C$, shoot tissue N:P versus shoot weight; D, root weight versus shoot weight. T30 CAL represents plant growth on sediment from transect 30 with high calcareous content. Critical range represents a range of critical concentrations observed to limit plant growth

but performed poorly for cattail and exhibited chlorosis and other evidence of stress. Trapa natans grew poorly in the tanks, and had extremely poor growth on Onondaga Lake sediments. All three species grown successfully on Lewisville sediments had significantly higher growth on the Lewisville sediment relative to Onondaga Lake sediments, with $N$. odorata doing well on the Lewisville sediment but poorly on the Onondaga Lake sediment, and $T$. natans and $S$. rigida doing poorly in the reconstructed Onondaga Lake water on all sediments, but even worse on the Onondaga Lake sediment.

Root growth showed even less variability than shoot growth (Figure 18). Only $V$. americana showed increased root growth on one Onondaga Lake sediment relative to another, showing a growth preference for the mixture, and a trend to performing better on the organic sediment. Vallisneria americana is typically thought of as a coarse sediment plant, but will grow well 

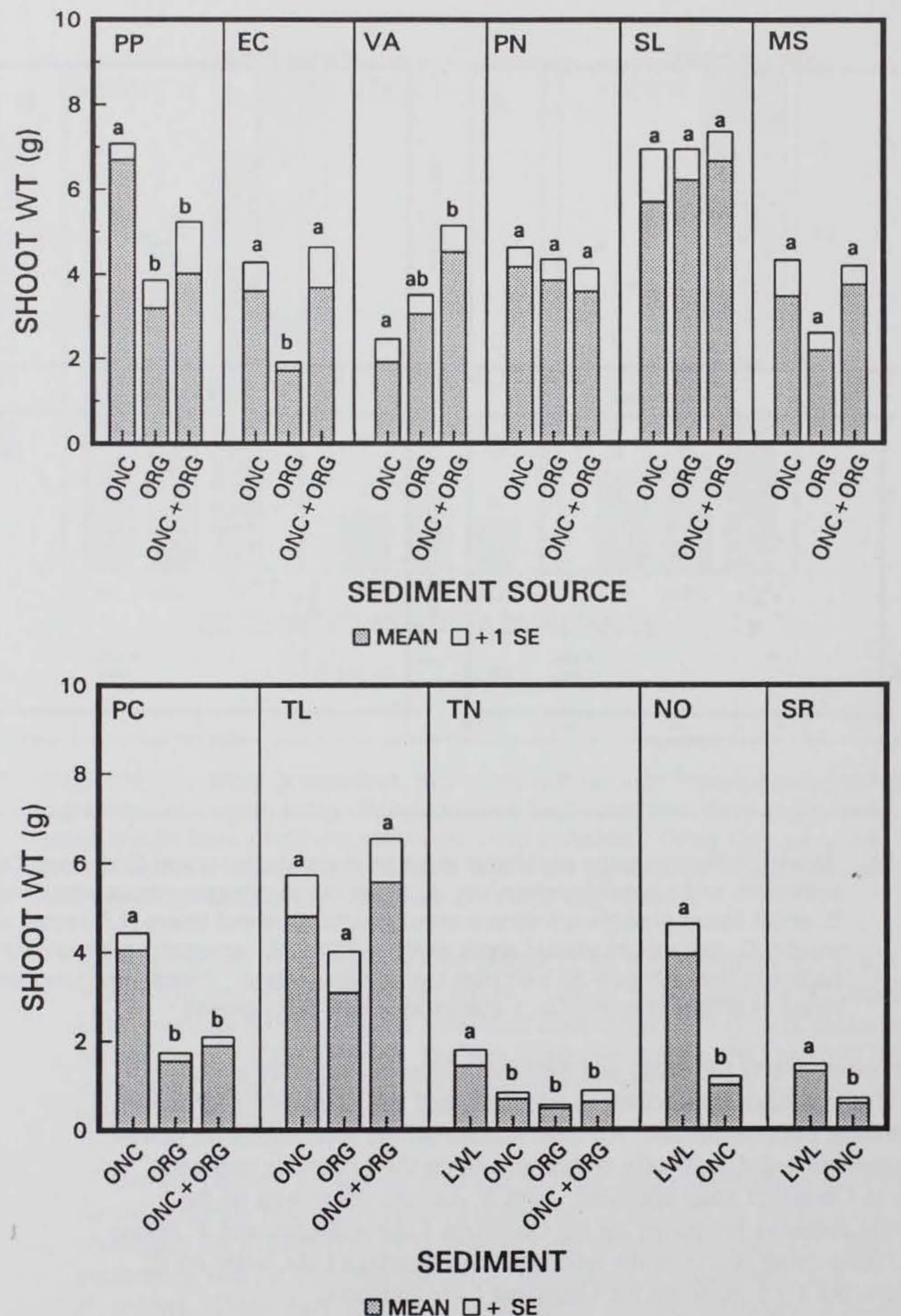

Figure 17. Shoot weight of aquatic plant species grown in greenhouse conditions using Onondaga Lake oncolite (ONC), organic (ORG), and mixture (ONC+ORG) sediments, and on a Lewisville reference ( $L W L$ ). Letter represents a significant difference between sediment sources for a given species using a one-way ANOVA and least significant difference test 

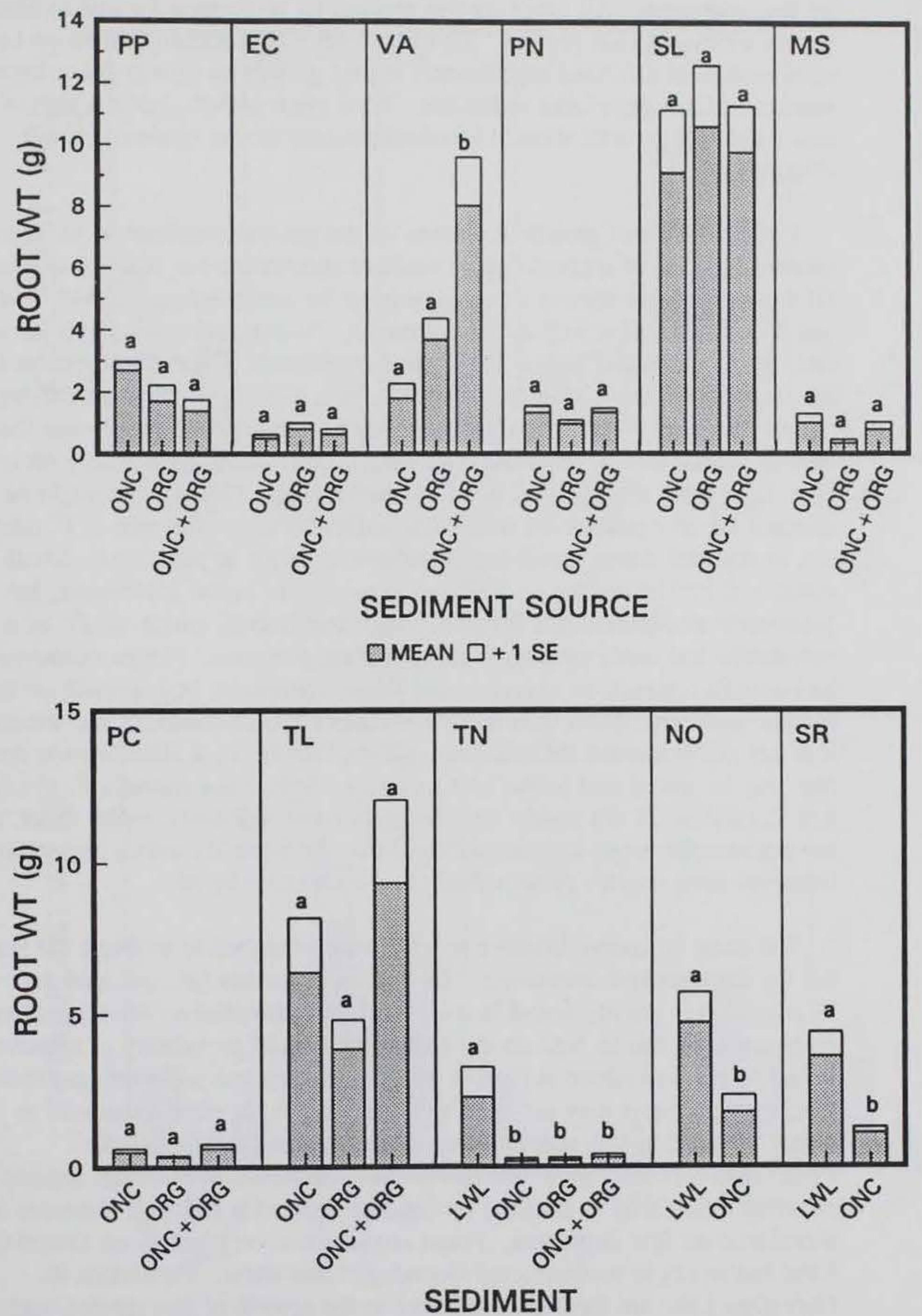

M MEAN $\square+$ SE

Figure 18. Root weight of aquatic plant species grown in greenhouse conditions using Onondaga Lake oncolite (ONC), organic (ORG), and mixture (ONC+ORG) sediments, and on a Lewisville reference ( $L W L$ ). Letter represents a significant difference between sediment sources for a given species using a one-way ANOVA and least significant difference test 
on fine sediments. All other species showed no preference for one sediment versus another in root growth. All three species successfully grown on Lewisville sediments exhibited significantly higher growth on Lewisville sediments relative to Onondaga Lake sediments. Total plant growth, being a sum of shoot and root growth, showed identical patterns to that of shoot growth (Figure 19).

Using both shoot growth and notes on the general condition of the plant, a relative estimate of success can be made to summarize our findings (Table 11). Of the eight native species to be considered for transplanting, two ( $P$. nodosus and $S$. latifolia) grew well on all sediments. Potamogeton pectinatus grew well on oncolites and fair on the organic sediments. These three species are the first choice for any transplant efforts, both because of good growth and because they are easily propagated and have a resistant tuber or turion that is easy to handle for transplanting. Vallisneria americana grew poorly on oncolites, fair on the organic, and good on the mixture. This species might be selected for revegetation on either fine sediments as an alternate to $P$. pectinatus, or for sites where rototilling of sediments might be attempted. Small rosettes to initiate studies on Vallisneria were used in the greenhouse, but Vallisneris also produces a dormant winter bud (tuber), which would be a convenient and hardy propagule for transplant purposes. Elodea canadensis had only fair growth on oncolites and mixed sediments, poor growth on the organic sediment. Since this species is more difficult to handle and transplant, it is not recommended for transplant efforts. However, it is a common species that may be introduced to the lake naturally. Nymphaea odorata, S. rigida, and $T$. latifolia all did poorly on Onondaga Lake sediments and/or water, and are not recommended for transplant efforts. As water chemistry and sediments improve, these species or ones similar may naturally invade.

The three nonnative invasive species were examined to evaluate the potential for invasion and dominance. Two of these species (M. spicatum and $P$. crispus) are already found in the lake in low abundance. Myriophyllum spicatum grew fair to well on the sediments. Initial probability of massive invasion and dominance at current water chemistry and sediment conditions are low, but conditions may not need to change much for rapid expansion to occur. Therefore, this species bears monitoring in Onondaga Lake.

Potamogeton crispus grew fair on oncolite sediments, poor on the organic and mixture; it will tend to increase on oncolite sediments before it increases in abundance on fine sediments. Trapa natans grew very poorly on Onondaga Lake sediments in reconstructed Onondaga Lake water. Conditions in Onondaga Lake are far from conducive to the growth of this species, and water chemistry will need to improve considerably before this species would become a threat to Onondaga Lake.

\section{Onondaga lake sediment seed bank}

Of the four sediments examined, the two coarse sediments (sand, T3; oncolite, T11) exhibited significantly higher seed emergence (29 and 


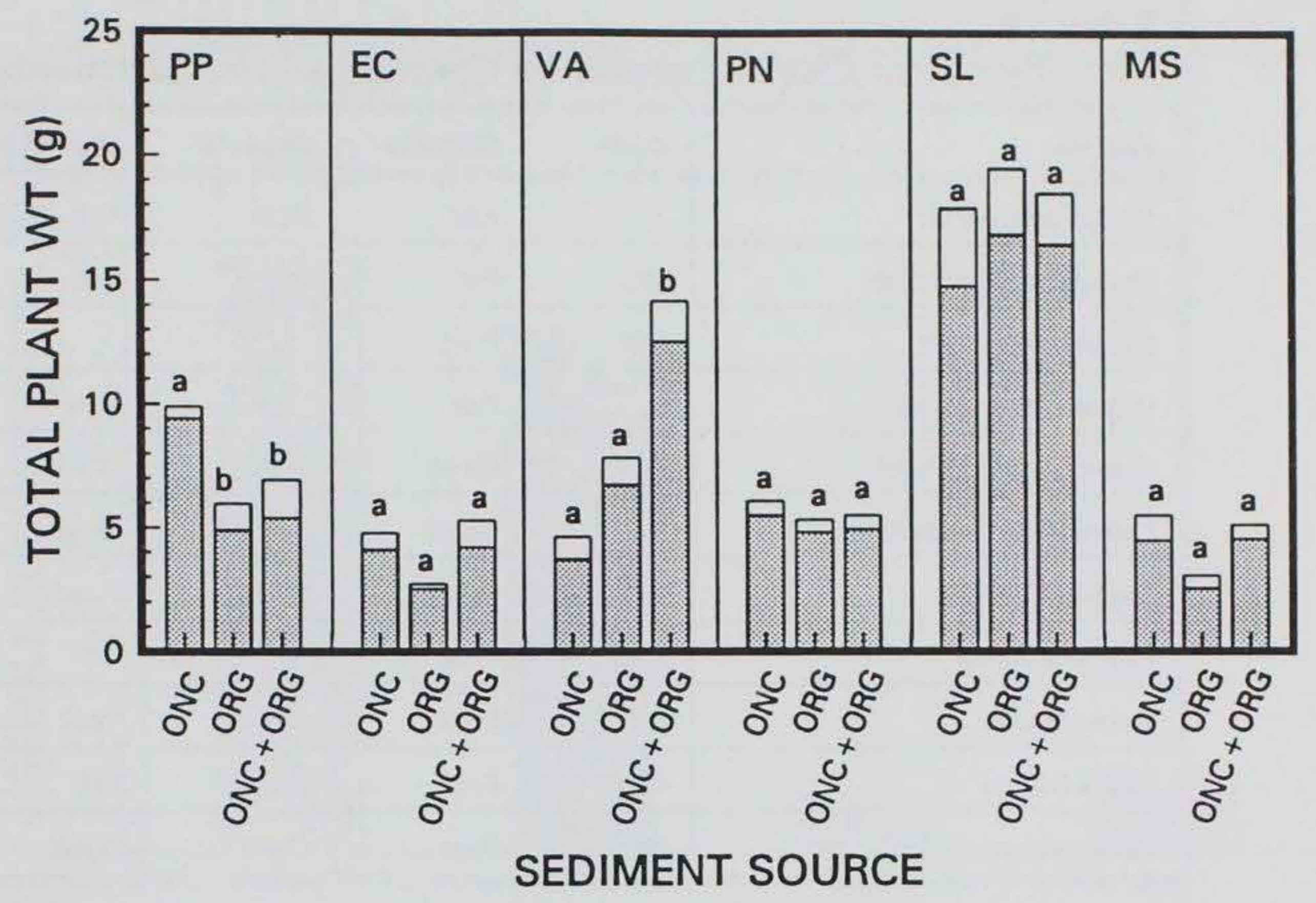

OMEAN $\square+1$ SE

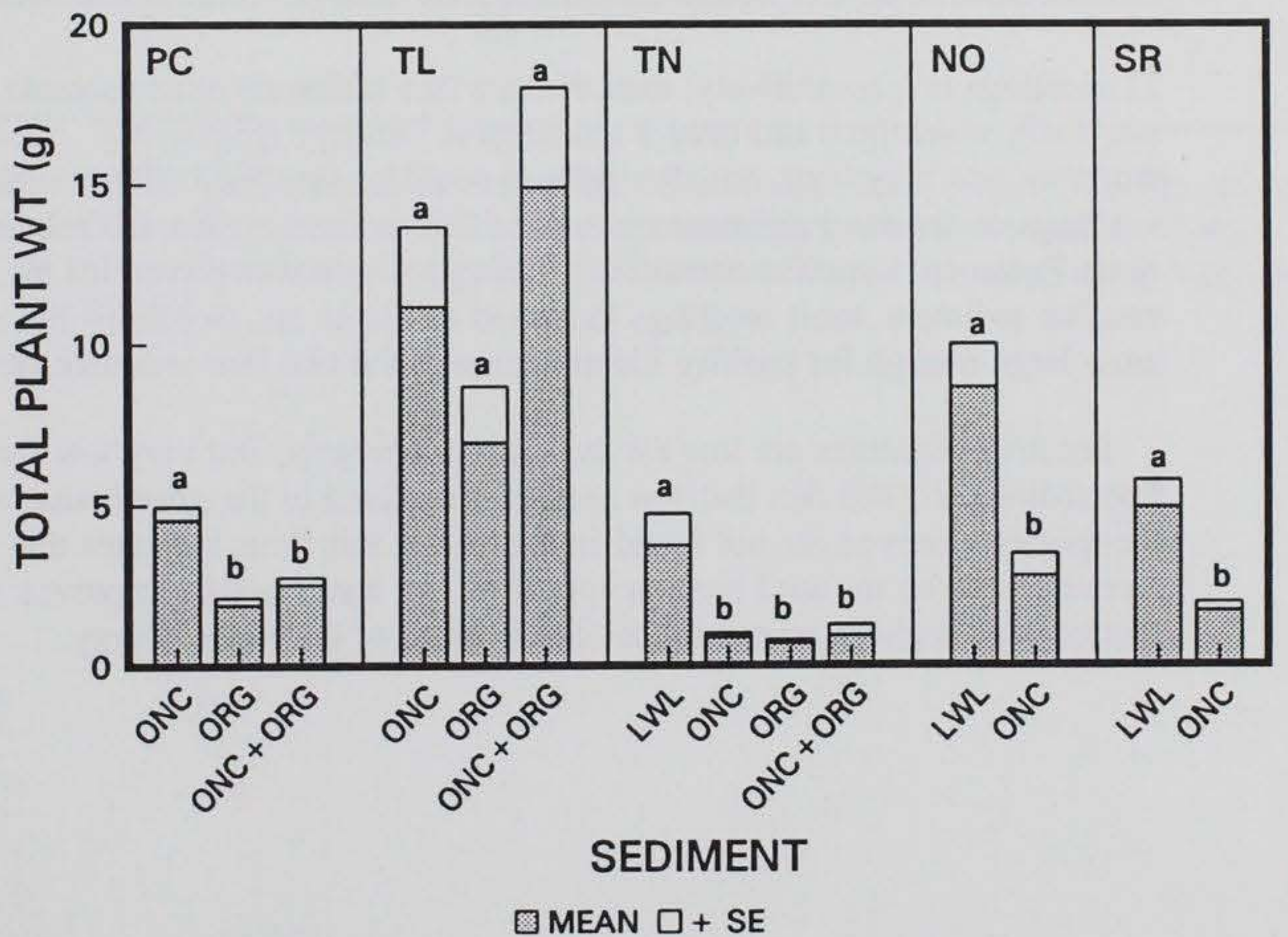

Figure 19. Total plant weight of aquatic plant species grown in greenhouse conditions using Onondaga Lake oncolite (ONC), organic (ORG), and mixture (ONC+ORG) sediments, and on a Lewisville reference (LWL). Letter represents a significant difference between sediment sources for a given species using a one-way ANOVA and least significant difference test 


\begin{tabular}{|l|l|l|l|l||}
\hline \hline \multicolumn{5}{||l}{$\begin{array}{l}\text { Table } 11 \\
\text { Performance of Eleven Species on Onondaga Lake Sediments }\end{array}$} \\
\hline \hline Specles & Code & Oncolite & Organic & Onc+Org \\
\hline \hline Elodea canadensis & EC & Fair & Poor & Fair \\
\hline Myriophyllum spicatum & MS & Fair & Fair & Fair \\
\hline Nymphaea odorata & NO & Poor & & \\
\hline Potamogeton crispus & PC & Fair & Poor & Poor \\
\hline Potamogeton nodosus & PN & Good & Good & Good \\
\hline Potamogeton pectinatus & PP & Good & Fair & Good \\
\hline Sagittaria latifolia & SL & Good & Good & Good \\
\hline Sagittaria rigida & SR & Poor & & \\
\hline Trapa natans & TN & Poor & Poor & Poor \\
\hline Typha latifolia & TL & Fair & Fair & Fair'|| \\
\hline Vallisneria americana & VA & Poor & Fair & Good \\
\hline \hline $\begin{array}{l}\text { 1 Although Typha latifolia had higher biomass than many other species, the plants were } \\
\text { chlorotic and the response was poor relative to what should be expected for this species. }\end{array}$ \\
\hline \hline
\end{tabular}

27 seedlings $\mathrm{m}^{-2}$, respectively) than the two fine sediments used (organic, T20; silt, T40), which both had only 3 seedlings $\mathrm{m}^{-2}$ emerge (Figure 20). Seedling mortality was very high; not all seedlings could be identified. The majority of seedlings on the sand sediment were identified as Juncus gerardii, although some Typha sp. were also identified. The opposite was observed for the oncolite sediment, most seedlings identified as Typha sp. Seedlings did not grow large enough for positive identification in the two fine sediment samples.

Seedbank densities are low for the coarse sediments, and very low for the fine sediments. The fact that few seedlings survived in the greenhouse, and the species observed are not found in the lake at this time, indicates that recruitment from the seed bank is very low. As water quality improves, these species may begin to recruit in the lake in areas of low wave energy. 


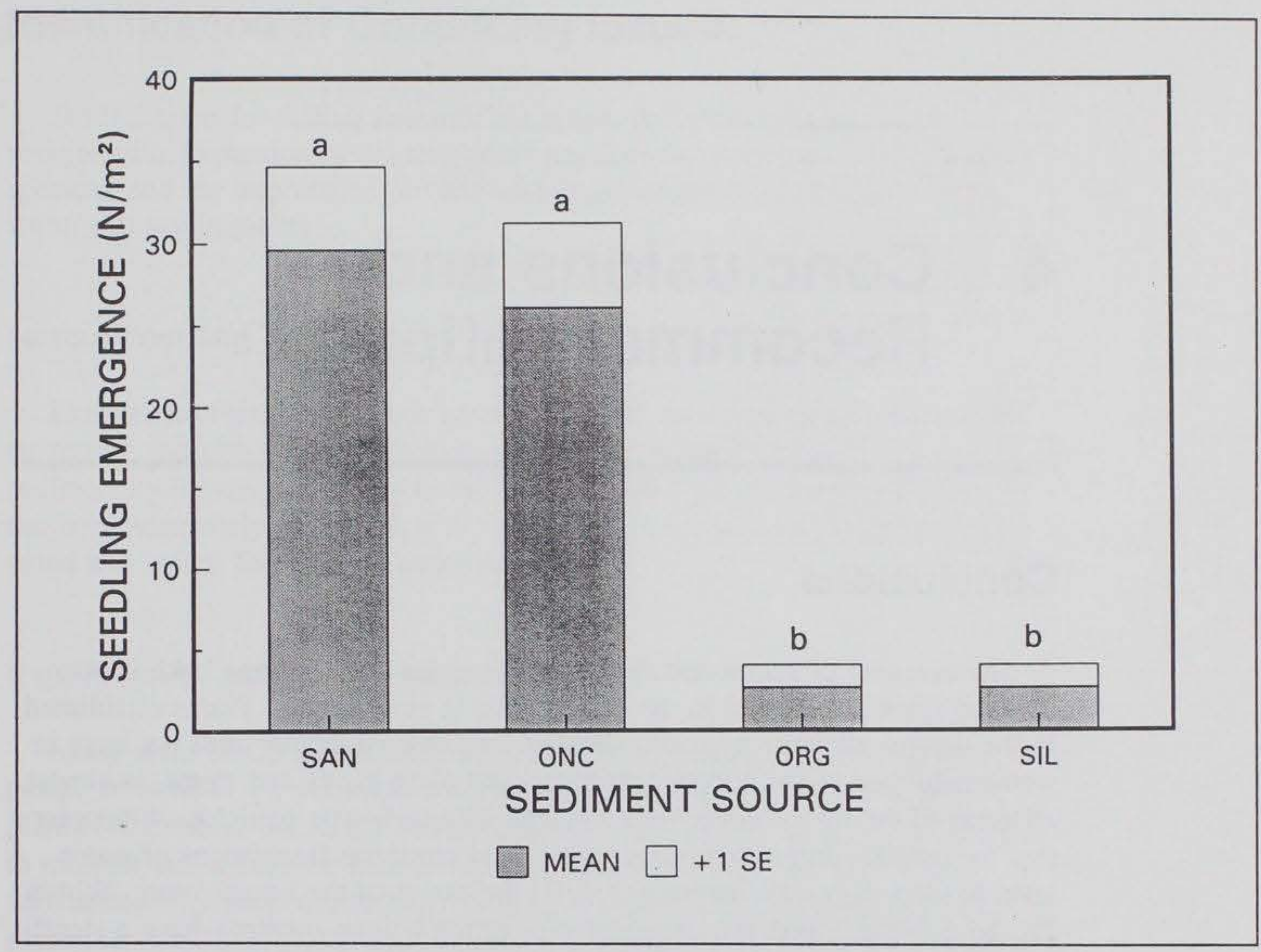

Figure 20. Seedling emergence from sand (SAN), oncolite (ONC), organic (ORG), and silt (SIL) sediments from Onondaga Lake under greenhouse conditions. Letter difference indicates a significant difference at the 0.05 leveling using a one-way ANOVA 


\section{Conclusions and Recommendations}

\section{Conclusions}

The diversity of submersed macrophyte species in Onondaga Lake is very low and plant distribution in the littoral zone is very patchy. Plants established in the bottom substrate appeared stressed, i.e., root structures were not large or well-established in the bottom substrates, and plant leaves and stems, in almost all areas of the littoral zone, were covered with carbonate particles. It appears that the combination of low transparency and moderate fluctuations of water level in Onondaga Lake severely restrict the extent of the littoral zone. Within this zone, wave action and characteristics of the bottom substrate have a significant effect on plant colonization. Even more striking during the 1991 survey was the absence of floating-leaved and emergent aquatic plants forming defined wetlands along the shoreline of Onondaga Lake.

Scattered, locally abundant submersed aquatic macrophyte communities dominated by Potamogeton pectinatus were documented in a 1991 survey. Although no quantitative data are available from even the recent past, it seems likely that the expansion of these submersed species is largely a recent phenomenon, and that submersed plants have existed in the lake for some time in quiet, protected areas. The major factors limiting submersed species have been water transparency, water chemistry (e.g., high solute concentrations), water level, and natural disturbance acting in concert, with the first two predominating. No emergent or floating-leaved species at or below the waterline were noted, which is a significant gap in the aquatic community. No single factor alone is responsible for the current distribution or past lack of aquatic plants, but many factors of varying significance or impact may be working in concert to control plant distribution and abundance. However, there are a few significant factors over which there is some control. By reducing water column salinity and reducing nutrient loadings, substantial improvements in water transparency will occur that will greatly benefit plant growth and survival. 


\section{Identification of Continuing Issues}

Several areas for further research are noted, including mercury cycling, revegetation, expansion of existing plant populations (both native and exotic species), and the importance of continued improvements in sediment composition and water quality.

\section{Mercury cycling}

Expansion of the macrophyte community will have general beneficial habitat results, but one possible negative impact is that macrophytes might make sedimentary mercury available to the aquatic food chain. This potential has not been adequately addressed, and most mercury models are pelagically oriented and ignore littoral zone contributions.

\section{Expansion of current plant distributions}

Many areas of Onondaga Lake have only small populations of aquatic plants, or none at all; yet these areas should support dense growths of native plants. Therefore, Onondaga Lake could provide a largely unique opportunity to monitor and model the natural reestablishment and early expansion of aquatic macrophyte communities. In addition to the expansion of native plants, it would provide an opportunity of studying two exotic nuisance plants at early stages of colonization.

\section{Revegetation}

The revegetation of freshwater littoral zone wetlands is still in experimental stages. Onondaga Lake vitally needs wetlands contiguous to the littoral zone to provide spawning areas for warmwater fish. This site provides an opportunity to develop methods applicable nationally and to create a needed habitat locally.

\section{Sediment composition and water quality improvements}

As solute concentrations decrease and sediment chemistry changes, plant communities and their interactions also will change. However, there is inadequate information to predict what will happen beyond the fact that changes will occur. 


\section{Recommendations}

\section{Remediation}

Based upon the results of the 1991 studies presented here, the primary objectives for remediation of the macrophyte community in Onondaga Lake can be stated as follows:

- Establish greater diversity, density, and distribution of rooted aquatic plants in the littoral zone of Onondaga Lake.

- Establish wetland areas along the shoreline of Onondaga Lake, or in areas adjacent to the shoreline and accessible from the lake.

\section{Management}

Alter the bottom substrate in selected areas of the littoral zone to stabilize existing sediment and to promote the establishment of aquatic macrophytes in areas where plants do not occur at the present time. Examples of alterations include the creation of artificial reefs or gravel beds to reduce the effect of wave action and promote establishment, and covering portions of the existing bottom substrate with geotextiles, such as Texel ${ }^{\mathrm{TM}}$, Aquascreen ${ }^{\mathrm{TM}}$, or other material, to reduce sediment or slope instability and provide an area for establishment of plants. These experimental plots could be "seeded" with several different species of aquatic macrophytes and the performance of the plants compared with plants transplanted to existing, unaltered bottom substrate. Associated with this effort would be a review, evaluation, and selection of appropriate species for wetland establishment on the basis of food preference for wildlife, effectiveness for shoreline stabilization, habitat improvement for fish and wildlife, growth habit, and availability.

\section{Monitoring}

Continue to monitor aquatic macrophytes in the lake during each growing season. In particular, monitor the expansion and decline of Potamogeton pectinatus (sago pondweed) colonies to evaluate the factors that influence growth and distribution.

\section{Research}

Conduct experiments to determine the role of submersed macrophytes in the transfer and cycling of mercury in Onondaga Lake. 


\section{References}

Allen, S. E., Grimshaw, H. M., Parkinson, J. A., and Quarmby, C. (1974). Chemical analysis of ecological materials. Wiley, New York.

American Public Health Association, American Water Works Association, and Water Pollution Control Federation. (1989). Standard methods for the examination of water and wastewater. 17th ed., American Public Health Association, Washington, DC.

Auer, M. T., Storey, M. L., Effler, S. W., Auer, N. A., and Sze, P. (1990). "Zooplankton impacts on chlorophyll and transparency in Onondaga Lake, New York, USA," Hydrobiologia 200/201:603-17.

Barko, J. W. (1983). "The growth of Myriophyllum spicatum L. in relation to selected characteristics of sediment and solution," Aquatic Botany 15:91-103.

Barko, J. W., and Smart, R. M. (1981). "Sediment-based nutrition of submersed macrophytes," Aquatic Botany 10:339-52.

. (1983). "Effects of organic matter additions to sediment on the growth of aquatic plants," Journal of Ecology 71:161-75.

(1986). "Sediment-related mechanisms of growth limitation in submersed macrophytes," Ecology 67:1328-40.

Bremner, J. M. (1965). "Inorganic forms of nitrogen." Methods of Soil Analysis, Part 2: Chemical and Microbiological Properties. Black, ed. American Society of Agronomy, Madison, WI, 1179-1237.

Canfield, D. E., Jr., Langeland, K. A., Linda, S. B., and Haller, W. T. (1985). "Relations between water transparency and maximum depth of macrophyte colonization in lakes," Journal of Aquatic Plant Management 23:25-8.

Chambers, P. A., and Kalff, J. (1985). "Depth distribution and biomass of submersed aquatic macrophyte communities in relation to Secchi depth," Canadian Journal of Fisheries and Aquatic Sciences 42:701-9. 
Chambers, P. A., and Prepas, E. E. (1988). "Underwater spectral attenuation and its effect on the maximum depth of angiosperm colonization," Canadian Journal of Fisheries and Aquatic Sciences 45:1010-17.

Daubenmire, R. (1959). "A canopy-coverage method of vegetational analysis," Northwest Science 33:43-64.

. (1968). Plant communities: A textbook of synecology. Harper and Row, New York.

Day, P. R. (1956). "Report of the committee on physical analyses," Soil Science Society of America Proceedings 20:167-69.

Dean, W. E. and Eggleston, J. R. (1984). "Freshwater oncolites created by industrial pollution, Onondaga Lake, New York," Sedimentary Geology 40:217-32.

Effler, S. W. (1987). "The impact of a chlor-alkali plant and adjoining systems," Water, Air, and Soil Pollution 33:85-115.

Effler, S. W., editor. (1992). State of Onondaga Lake report. Onondaga Lake Management Conference, Syracuse, NY. In prep.

Effler, S. W., Brooks, C. M., Auer, M. T., and Doerr, S. M. (1990). "Free ammonia and toxicity criteria in a polluted urban lake," Journal of the Water Pollution Control Federation 62(6): 771-79.

Effler, S. W., and Driscoll, C. T. (1985). "Calcium chemistry and deposition in ionically enriched Onondaga Lake, New York," Environmental Science and Technology 19:716-20.

Effler, S. W., Perkins, M. G., and Brooks, C. M. (1986). "The oxygen resources of the hypolimnion of ionically enriched Onondaga Lake, NY, USA," Water, Air, and Soil Pollution 29: 93-108.

Eichler, L. W. (1990). "Assessment of Brant Lake," Rensselaer Fresh Water Institute Report \#90-17, Rensselaer Polytechnic Institute, Troy, NY.

Eichler, L. W., and Madsen, J. D. (1990a). "Assessment of Lake Luzerne," Rensselaer Fresh Water Institute Report \#90-2, Rensselaer Polytechnic Institute, Troy, NY.

. (1990b). "Assessment of Galway Lake," Rensselaer Fresh Water Institute Report \#90-5, Rensselaer Polytechnic Institute, Troy, NY.

. (1990c). "Assessment of Eagle Lake," Rensselaer Fresh Water Institute Report \#90-6, Rensselaer Polytechnic Institute, Troy, NY.

Fassett, N. C. (1957). A manual of aquatic plants. 2nd ed. (revised by E. C. Ogden), University of Wisconsin Press, Madison. 
Field, S. D., and Effler, S. W. (1983). "Light attenuation in Onondaga Lake, NY, USA, 1978," Hydrobiologia 98:409-21.

Gilman, B. (1985). An inventory of the aquatic weedbeds of Honeoye Lake with suggestions for their management. Community College of the Finger Lakes, Canandaigua, NY.

Haller, W. T., Sutton, D. L., and Barlowe, W. C. (1974). "Effects of salinity on growth of several aquatic macrophytes," Ecology 55:891-94.

Hammer, U. T., and Heseltine, J. M. (1988). "Aquatic macrophytes in saline lakes of the Canadian prairies," Hydrobiologia 158:101-16.

Hutchinson, G. E. (1975). A treatise on Limnology. Vol. III. Limnological Botany. Wiley, New York.

Johnstone, I. M., Coffey, B. T., and Howard-Williams, C. (1985). "The role of recreational boat traffic in the interlake dispersal of macrophytes: A New Zealand case study," Journal of Environmental Management 20:263-79.

Kadono, Y. (1982). "Occurrence of aquatic macrophytes in relation to $\mathrm{pH}$, alkalinity, $\mathrm{Ca}^{++}, \mathrm{Cl}^{\text {, }}$, and conductivity," Japanese Journal of Ecology 32:39-44.

Madsen, J. D. (1991). "Bibliography of critical tissue nutrient concentrations in submersed aquatic macrophytes and tissue nutrient concentrations in sago pondweed (Potamogeton pectinatus L.)," Rensselaer Fresh Water Institute Report \#91-1, Rensselaer Polytechnic Institute, Troy, NY.

Madsen, J. D. (1992). "Seasonal tissue nutrient composition of Potamogeton pectinatus L. in Badfish Creek, Wisconsin," submitted to Hydrobiologia.

Madsen, J. D., Sutherland, J. W., Bloomfield, J. A., Roy, K. M., Eichler, L. W., and Boylen, C. W. (1989). Lake George aquatic plant survey final report. New York State Department of Environmental Conservation, Albany, NY.

McMullen, J. M. (1991). Aquatic vascular plants of Onondaga Lake - A comparison of recent finds to historical records. Terrestrial Environmental Specialists, Inc., Phoenix, NY. (Unpubl. report.)

Miller, G. L. (1978). An ecological inventory of aquatic vegetation in the major lakes of Cayuga County New York and recommendations for their management. Cayuga County Environmental Management Council, Auburn, NY.

Nichols, S. A., and Shaw, B. H. (1986). Ecological life histories of the three aquatic nuisance plants, Myriophyllum spicatum, Potamogeton crispus, and Elodea canadensis. Hydrobiologia 131:3-21. 
Saroff, S. T., editor. (1990). Proceedings of the Onondaga Lake Remediation Conference. Sagamore Conference Center, Bolton Landing, NY, 5-8 Feb 1990. New York State Office of Attorney General, Albany, NY.

Smart, R. M. (1990). "Effects of Water Chemistry on Submersed Aquatic Plants: A Synthesis," Miscellaneous Paper A-90-4, U.S. Army Engineer Waterways Experiment Station, Vicksburg, MS.

Smart, R. M., and Barko, J. W. (1988). "Effects of water chemistry on aquatic plants: Interrelationships among biomass production, plant nutrition, and water chemistry," Technical Report A-88-5, U.S. Army Engineer Waterways Experiment Station, Vicksburg, MS.

Stone, U. B., and Pasko, D. (1946). Onondaga Lake investigation. Westem District, NYS Conservation Department.

Taggett, L. J. (1989). "Aquatic plant inventory of the Lake George region," Rensselaer Fresh Water Institute Report \#89-2, Rensselaer Polytechnic Institute, Troy, NY.

Taggett, L. J., Madsen, J. D., and Boylen, C. W. (1990). "Annotated bibliography for species richness for submersed aquatic plants in worldwide waterways," Rensselaer Fresh Water Institute Report \#90-9, Rensselaer Polytechnic Institute, Troy, NY.

Tobiessen, P., and Snow, P. D. (1984). "Temperature and light effects on the growth of Potamogeton crispus in Collins Lake, New York State," Canadian Journal of Botany 62:2822-26.

U.S. Senate, Committee on Environment and Public Works, Sub-committee on Water Resources, Transportation and Infrastructure. (1989). Onondaga Lake Restoration Act of 1989. Hearing 101-80, U.S. Government Printing Office, Washington, DC.

Vant, W. N., Davies-Colley, R. J., Clayton, J. S., and Coffey, B. T. (1986). "Macrophyte depth limits in North Island (New Zealand) lakes of differing clarity," Hydrobiologia 137:55-60.

Wetzel, R. G. (1960). "Marl encrustation on hydrophytes in several Michigan lakes," Oikos 11:223-36.

(1983). Limnology. 2nd ed., Saunders, Philadelphia. 
Public reporting burden for this collection of information is estimated to average 1 hour per response, including the time for reviewing instructions, searching existing data sources. gathering and maintaining the data needed, and completing and reviewing the collection of information. Send comments regarding this burden estimate or any other aspect of this collection of information, including suggestions for reducing this burden, to Washington Headquarters Services, Directorate for information Operations and Reports, 1215 Jefferson Davis Highway, Suite 1204. Arlington, VA 22202-4302, and to the Office of Management and Budget, Paperwork Reduction Project (0704-0188), Washington, DC 20503.

\section{AGENCY USE ONLY (Leave blank) \\ 2. REPORT DATE \\ August 1993 \\ 3. REPORT TYPE AND DATES COVERED \\ Final report}

\section{Submersed Littoral Vegetation Distribution: Field Quantification}

5. FUNDING NUMBERS

and Experimental Analysis of Sediment Types From Onondaga Lake,

New York

\section{AUTHOR(S)}

John D. Madsen, Lawrence W. Eichler, James W. Sutherland,

Jay A. Bloomfield, R. Michael Smart, Chester W. Boylen

\section{PERFORMING ORGANIZATION NAME(S) AND ADDRESS(ES)}

U.S. Army Engineer Waterways Experiment Station

3909 Halls Ferry Road, Vicksburg, MS 39180-6199

Rensselaer Polytechnic Institute, Troy, NY 12180-3590

New York State Department of Environmental Conservation

50 Wolf Road, Albany, NY 12233-3502

9. SPONSORING/MONITORING AGENCY NAME(S) AND ADDRESS(ES)

Headquarters, U.S. Army Corps of Engineers

Washington, DC 20314-1000
8. PERFORMING ORGANIZATION REPORT NUMBER

Technical Report

A-93-14

\section{SUPPLEMENTARY NOTES}

Available from National Technical Information Service, 5285 Port Royal Road, Springfield, VA 22161

12a. DISTRIBUTION/AVAILABILITY STATEMENT

12b. DISTRIBUTION CODE

Approved for public release; distribution is unlimited.

\section{ABSTRACT (Maximum 200 words)}

Onondaga Lake, located in upstate New York near Syracuse, has been heavily impacted by industrial and domestic effluent. Due to these impacts, the native littoral vegetation had largely disappeared. The primary purpose of this research is to revegetate the littoral zone of the lake. In order to achieve this goal, field and greenhouse studies were performed to evaluate factors limiting the growth of aquatic plants. Species selected for greenhouse studies included sago pondweed, Eurasian watermilfoil, water celery, elodea, curly-leaf pondweed, waterchestnut, American pondweed, white water-lily, cattail, arrowhead, and rigid-leaf arrowhead.

Only 13 percent of 3,497 quadrats examined in the lake had aquatic plants. The most common plant was sago pondweed (Potamogeton pectinatus, 11 percent); water stargrass (Heteranthera dubia, 2 percent), curly-leaf pondweed (Potamogeton crispus, 0.3 percent), coontail (Ceratophyllum demersum, 0.3 percent), and Eurasian watermilfoil (Myriophyllum spicatum, 0.06 percent) were also found.

(Continued)

\begin{tabular}{|c|c|c|c|}
\hline \multicolumn{3}{|l|}{ 14. SUBJECT TERMS } & 15. NUMBER OF PAGES \\
\hline $\begin{array}{l}\text { Aquatic plants } \\
\text { Littoral zone }\end{array}$ & \multicolumn{2}{|l|}{$\begin{array}{l}\text { Macrophytes } \\
\text { Sediment }\end{array}$} & 16. PRICE CODE \\
\hline $\begin{array}{l}\text { 17. SECURITY CLASSIFICATION } \\
\text { OF REPORT } \\
\text { UNCLASSIFIED }\end{array}$ & $\begin{array}{l}\text { 18. SECURITY CLASSIFICATION } \\
\text { OF THIS PAGE } \\
\text { UNCLASSIFIED }\end{array}$ & $\begin{array}{l}\text { 19. SECURITY CLASSIFICATION } \\
\text { OF ABSTRACT } \\
\text { UNCLASSIFIED }\end{array}$ & 20. LIMITATION OF ABSTRACT \\
\hline
\end{tabular}




\section{3. (Concluded).}

Growth of sago pondweed on Onondaga Lake sediments was correlated to the abundance of plants in situ, indicating that growth limitation of plants in the lake was partially due to sediment-based nutrition. Growth on Onondaga Lake sediments was substantially below the reference sediment. Tests of different species indicated several plants could be used to revegetate Onondaga Lake littoral zones, depending on the sediment type. Sago pondweed $(P$. pectinatus), American pondweed $(P$. nodosus), and arrowhead ( $S$. latifolia) were the three most successful and desirable plants for revegetation efforts. 